\title{
Asian chemical outflow to the Pacific in spring: Origins, pathways, and budgets
}

\section{Citation}

Bey, Isabelle, Daniel J. Jacob, Jennifer. A. Logan, and Robert M. Yantosca. 2001. "Asian Chemical Outflow to the Pacific in Spring: Origins, Pathways, and Budgets." Journal of Geophysical Research 106 (D19): 23097. doi:10.1029/2001jd000806. http://dx.doi.org/10.1029/2001JD000806.

\section{Published Version}

doi:10.1029/2001JD000806

\section{Permanent link}

http://nrs.harvard.edu/urn-3:HUL.InstRepos:14061858

\section{Terms of Use}

This article was downloaded from Harvard University's DASH repository, and is made available under the terms and conditions applicable to Other Posted Material, as set forth at http:// nrs.harvard.edu/urn-3:HUL.InstRepos:dash.current.terms-of-use\#LAA

\section{Share Your Story}

The Harvard community has made this article openly available.

Please share how this access benefits you. Submit a story.

Accessibility 


\title{
Asian chemical outflow to the Pacific in spring: Origins, pathways, and budgets
}

\author{
Isabelle Bey, ${ }^{1}$ Daniel J. Jacob, Jennifer. A. Logan, and Robert M. Yantosca \\ Division of Engineering and Applied Sciences, and Department of Earth and Planetary Sciences, \\ Harvard University, Massachusetts
}

\begin{abstract}
We analyze the Asian outflow of $\mathrm{CO}$, ozone, and nitrogen oxides $\left(\mathrm{NO}_{x}\right)$ to the Pacific in spring by using the GEOS-CHEM global three-dimensional model of tropospheric chemistry and simulating the Pacific Exploratory Mission-West (PEM-West B) aircraft mission in February-March 1994. The GEOS-CHEM model uses assimilated meteorological fields from the NASA Goddard Earth Observing System (GEOS). It reproduces relatively well the main features of tropospheric ozone, $\mathrm{CO}$, and reactive nitrogen species observed in PEM-West B, including latitudinal and vertical gradients of the Asian pollution outflow over the western Pacific although simulated concentrations of $\mathrm{CO}$ tend to be too low (possibly because biogenic sources are underestimated). We use $\mathrm{CO}$ as a long-lived tracer to diagnose the processes contributing to the outflow. The highest concentrations in the outflow are in the boundary layer $(0-2 \mathrm{~km})$, but the strongest outflow fluxes are in the lower free troposphere $(2-5 \mathrm{~km})$ and reflect episodic lifting of pollution over central and eastern China ahead of eastward moving cold fronts. This frontal lifting, followed by westerly transport in the lower free troposphere, is the principal process responsible for export of both anthropogenic and biomass burning pollution from Asia. Anthropogenic emissions from Europe and biomass burning emissions from Africa make also major contributions to the Asian outflow over the western Pacific; European sources dominate in the lower troposphere north of $40^{\circ} \mathrm{N}$, while African sources are important in the upper troposphere at low latitudes. For the period of PEM-West B (February-March) we estimate that fossil fuel combustion and biomass burning make comparable contributions to the budgets of $\mathrm{CO}$, ozone, and $\mathrm{NO}_{x}$ in the Asian outflow. We find that $13 \%$ of $\mathrm{NO}_{x}$ emitted in Asia is exported as $\mathrm{NO}_{x}$ or PAN, a smaller fraction than for the United States because of higher aerosol concentrations that promote heterogeneous conversion of $\mathrm{NO}_{x}$ to $\mathrm{HNO}_{3}$. Production and export of ozone from Asia in spring is much greater than from the United States because of the higher photochemical activity.
\end{abstract}

\section{Introduction}

Rapid industrialization of eastern Asia is expected to have important implications for global atmospheric chemistry over the next decades [Berntsen et al., 1996] and also perhaps for surface air pollution over North America [Berntsen et al., 1999; Jaffe et al., 1999; Jacob et al., 1999]. Akimoto and Narita [1994] reported a 65\% increase of nitrogen oxides $\left(\mathrm{NO}_{x}\right)$ emissions in eastern Asia between 1975 and 1987, and van Aardenne et al. [1999] predict an increase of almost five fold in $\mathrm{NO}_{x}$ emissions from 1990 to 2020. By contrast, little change and even decrease can be expected for $\mathrm{NO}_{x}$ emissions in North America or western Europe due to emission controls [Environmental Protection

${ }^{1}$ Now at Swiss Federal Institute of Technology, Lausanne, Switzerland. Copyright 2001 by the American Geophysical Union.

Paper number 2001JD000806. 0148-0227/01/2001JD000806\$09.00
Agency (EPA), 1996], making Asia the more important anthropogenic emitter over the next 20 years. There is thus a need to better understand the chemical processing of emissions over Asia and the mechanisms for export of this pollution to the global atmosphere.

In this paper, we use a global three-dimensional (3-D) model of tropospheric chemistry driven by assimilated meteorological observations [Bey et al., this issue] to examine Asian outflow over the western Pacific through simulations of the Pacific Exploratory Mission (PEM) West B aircraft mission in February-March 1994 [Hoell et al., 1997]. The PEM-West B mission used a DC-8 aircraft operating out of Hong Kong, Japan, and Guam to survey the western Pacific atmosphere up to $12 \mathrm{~km}$ altitude (Figure 1). The mission was flown in late winter-early spring, the season of strongest Asian outflow to the Pacific [Merrill, 1989; Balkanski et al., 1992].

Data from PEM-West B showed that the chemical outflow from Asia is a complex mixture. Koike et al. [1997] pointed out the diversity of $\mathrm{NO}_{x}$ origins: in addition to fossil 


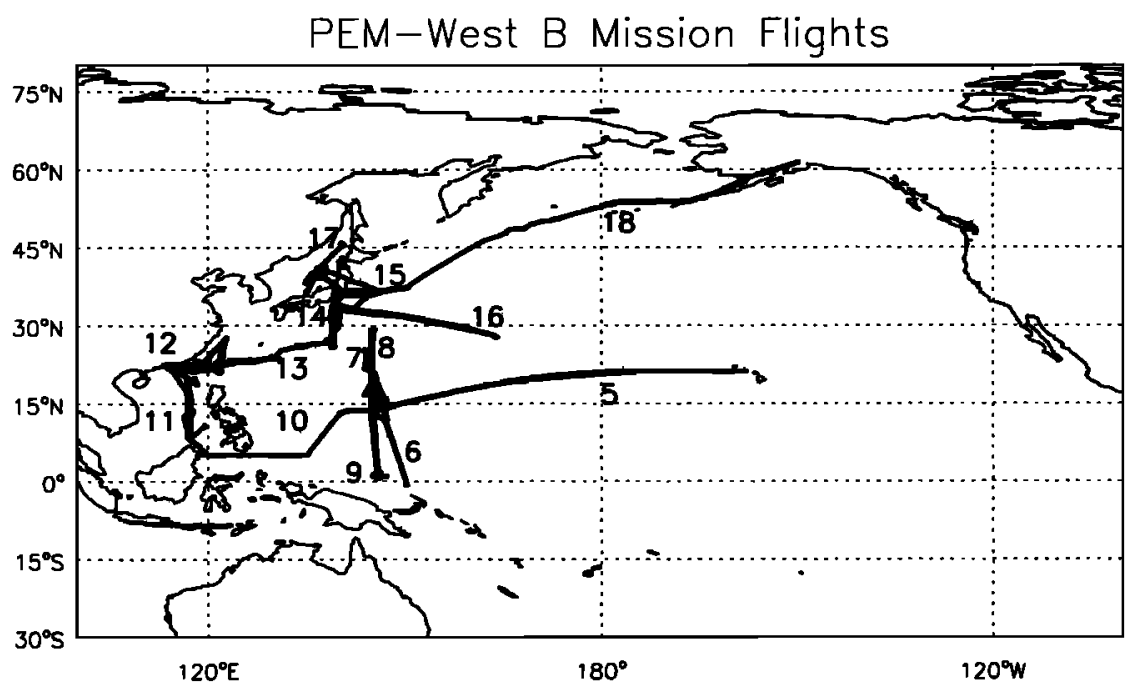

Figure 1. Flight tracks of the PEM-West B mission (February-March 1994). Flights number are indicated.

fuel sources, there was evidence of significant contributions from aircraft exhaust and lightning. The hydrocarbon and halocarbon data of Blake et al. [1997] identified various chemical signatures in the Asian outflow, including fossil fuel combustion and biomass burning. Liu et al. [1999] and Chan et al. [2000] found that biomass burning taking place in Southeast Asia could explain enhancements of ozone concentrations in spring over Hong Kong. Talbot et al. [1997] examined correlations between various hydrocarbon, halocarbon, nitrogen oxides and ozone concentrations from PEM-West $B$ and found aged air masses with an industrial signature which could have been advected from Europe or the Middle East. Moreover, the presence of high aerosol concentrations in the Asian outflow, including sulfate and nitrate aerosols as well as mineral aerosols [Chen et al., 1997], further complicates the composition of the outflow and its evolution [Zhang and Carmichael, 1999].

Previous analyses of the Asian outflow have focused on quantifying the impact of anthropogenic Asian emissions on global tropospheric composition [Berntsen et al., 1996] and on the composition of air masses reaching North America [Jacob et al., 1999; Berntsen et al., 1999; Yienger et al., 2000]. More interest needs to be given to the Asian outflow in terms of quantification of the flux exported and the mechanisms involved in the export. Using a regional model, Carmichael et al. [1998] found that stratospheric intrusions as well as Asian outflow contribute significantly to ozone concentrations in surface air over Japan. Yienger et al. [2000] showed that convergence over Asia makes a major contribution to the Asian outflow over the western Pacific. In the present study, we focus on quantifying the Asian export of $\mathrm{CO}, \mathrm{NO}_{x}$ and ozone, which are of particular interest for driving global atmospheric chemistry. Our simulation uses the GEOS-CHEM global 3-D model of tropospheric chemistry with assimilated meteorological observations for 1994, and our evaluation of model results focuses on PEMWest $B$ observations. We identify the major pathways and meteorological drivers for export of Asian pollution, esti- mate the role of chemical processing over the continent, and quantify the contributions from various sources including biomass burning and intercontinental transport to the Asian outflow over the western Pacific.

\section{Model Description}

The GEOS-CHEM model is a global model of tropospheric chemistry driven by assimilated meteorological observations from the Goddard Earth Observing System (GEOS) of the NASA Data Assimilation Office (DAO). A full description of the model is given by Bey et al. [this issue]. For the present work, we use meteorological fields for 1993 and 1994 (GEOS-1) which are provided with horizontal resolution of $2^{\circ}$ latitude by $2.5^{\circ}$ longitude and 20 sigma levels in the vertical, from the surface up to $10 \mathrm{hPa}$. For some of the work presented here, we regrid the GEOS data to a horizontal resolution of $4^{\circ}$ latitude by $5^{\circ}$ longitude which saves a factor of 8 in computation time.

The model includes 80 chemical species and carries 24 tracers to describe tropospheric $\mathrm{O}_{3}-\mathrm{NO}_{x}$-hydrocarbons chemistry. Emissions include anthropogenic activities, biomass burning, sources from the biosphere, and lightning. Anthropogenic emissions are distributed on the basis of inventories for 1985 and are scaled to 1994 levels on the basis of energy use statistics [Bey et al., this issue]. Biomass burning emissions are from a climatological inventory with a monthly temporal resolution [Wang et al., 1998]. Lightning emission of $\mathrm{NO}_{x}$ occurs in conjunction with deep convective events in the GEOS data following the parameterizations of Price and Rind [1992] and Pickering et al. [1998]. Advection is computed with a flux-form semi-Lagrangian method described by Lin and Rood [1996]. Moist convection is computed using the GEOS convective, entrainment, and detrainment mass fluxes as described by Allen et al. [1996a,1996b]. Full vertical mixing is assumed up to the GEOS-diagnosed mixing depth.

A global evaluation of the model is presented by Bey 


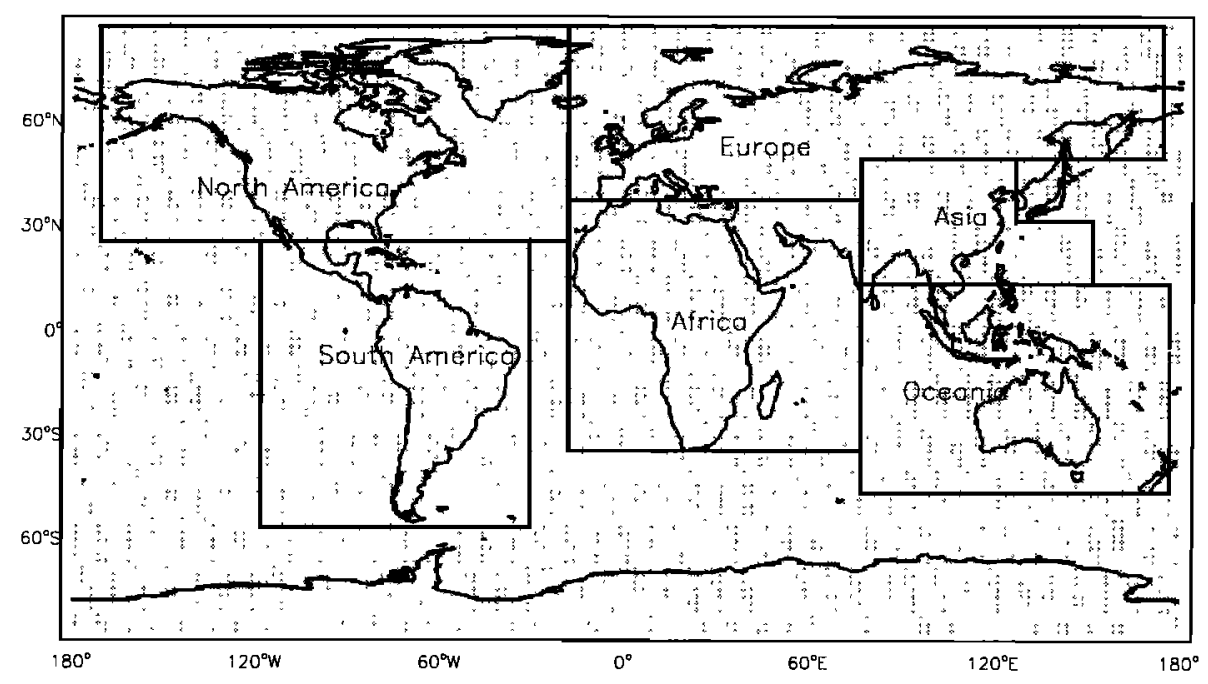

Figure 2. Model grid $\left(2^{\circ} \times 2.5^{\circ}\right)$ and geopolitical source regions used for model analysis.

et al. [this issue], using meteorological fields for 1994. This evaluation includes comparisons with climatological and 1994 ozonesonde data, long-term and 1994 observations of $\mathrm{CO}$ at surface sites, aircraft observations of NO, PAN, $\mathrm{HNO}_{3}$, hydrocarbons and acetone, and the atmospheric lifetime of methylchloroform as a proxy of the global mean $\mathrm{OH}$ concentrations. The global evaluation shows that the main features of ozone concentrations in the troposphere are well captured by the model; diagnosed problems include a low seasonal amplitude in the middle troposphere at northern midlatitudes. Modeled nitrogen species (NO, PAN, and $\mathrm{HNO}_{3}$ ) are usually within a factor 2 of observed values although the model overestimates $\mathrm{HNO}_{3}$. The lifetime of methylchloroform against oxidation by tropospheric $\mathrm{OH}$ is 5.1 years in our model, as compared to a best estimate of 5.5 years by Spivakovsky et al. [2000]. Simulated CO concentrations are in general too low (by 5 to $20 \mathrm{ppb}$ in most of the cases). As discussed by Bey et al. [2001], it is not clear whether this underestimate reflects excessive $\mathrm{OH}$ concentrations in the model or an undercounting of $\mathrm{CO}$ sources from oxidation of biogenic hydrocarbons.

We present here a more focused evaluation of the model with observations from PEM-West B, sampling the model along the aircraft flight tracks and for the specific flight day. We use for that purpose a version of the model including full $\mathrm{O}_{3}-\mathrm{NO}_{x}$-hydrocarbons chemistry and $4^{\circ} \times 5^{\circ}$ horizontal resolution. The simulation is conducted from June 1993 to March 1994, starting from climatological values as initial conditions. The 7-month initialization from June 1993 to January 1994 effectively removes the effect of initial conditions, and results from February-March 1994 are used to compare with the observations.

We also present in this paper a $\mathrm{CO}$ simulation with the original $2^{\circ} \times 2.5^{\circ}$ horizontal resolution to better resolve the structure in the Asian outflow and to diagnose any failures of the coarser resolution in representing major features of transport. This CO-only simulation uses eight tagged $\mathrm{CO}$ tracers to resolve source regions contributing to Asian outflow: four tracers for fuel combustion including fossil fuel and wood (North America, Europe, Asia, and rest of the world) and four tracers for biomass burning (South America, Africa, Asia, and rest of the world). The corresponding domains are given in Figure 2. Loss of $\mathrm{CO}$ by reaction with $\mathrm{OH}$ and production of $\mathrm{CO}$ from oxidation of isoprene and methane by $\mathrm{OH}$ (using molar yields of 1.25 and 1, respectively) are calculated using $\mathrm{OH}$ monthly mean fields generated with the standard simulation described previously. The source of $\mathrm{CO}$ due to oxidation of hydrocarbons other than methane and isoprene is relatively small and is ignored. By summing the concentrations of all $\mathrm{CO}$ tracers we reproduce closely the $\mathrm{CO}$ concentrations obtained in the standard full-chemistry simulation.

\section{Comparison With Observations from the PEM-West B Mission}

In comparing the model results with the PEM-West B aircraft observations, we sample the model along the flight tracks and for the specific flight days. We use 24-hour average model results for the flight days; considering the $4^{\circ} \times 5^{\circ}$ spatial resolution of the model and the 6-hour temporal resolution of the GEOS meteorological data, any finer temporal detail in comparing model results to observations would be illusory. Additional evaluation of model results with time series of meteorological variables and $\mathrm{CO}$ concentrations measured at a Taiwan site during PEM-West B [Liu et al., 1997] is presented in section 4 in the context of analysis of frontal passages.

The comparison between model results and the PEMWest B observations results is carried out in two ways. Figure 3 compares the latitudinal and longitudinal distributions of selected species $\left(\mathrm{O}_{3}, \mathrm{CO}, \mathrm{C}_{2} \mathrm{H}_{6}, \mathrm{NO}, \mathrm{PAN}, \mathrm{HNO}_{3}\right)$ in the PEM-West $\mathrm{B}$ observations and in the model in order to show the capability of the model over the whole region of interest. Observations were averaged over $5^{\circ}$ latitude bands for the lower troposphere (below $6 \mathrm{~km}$ ) (Figure 3a) and 

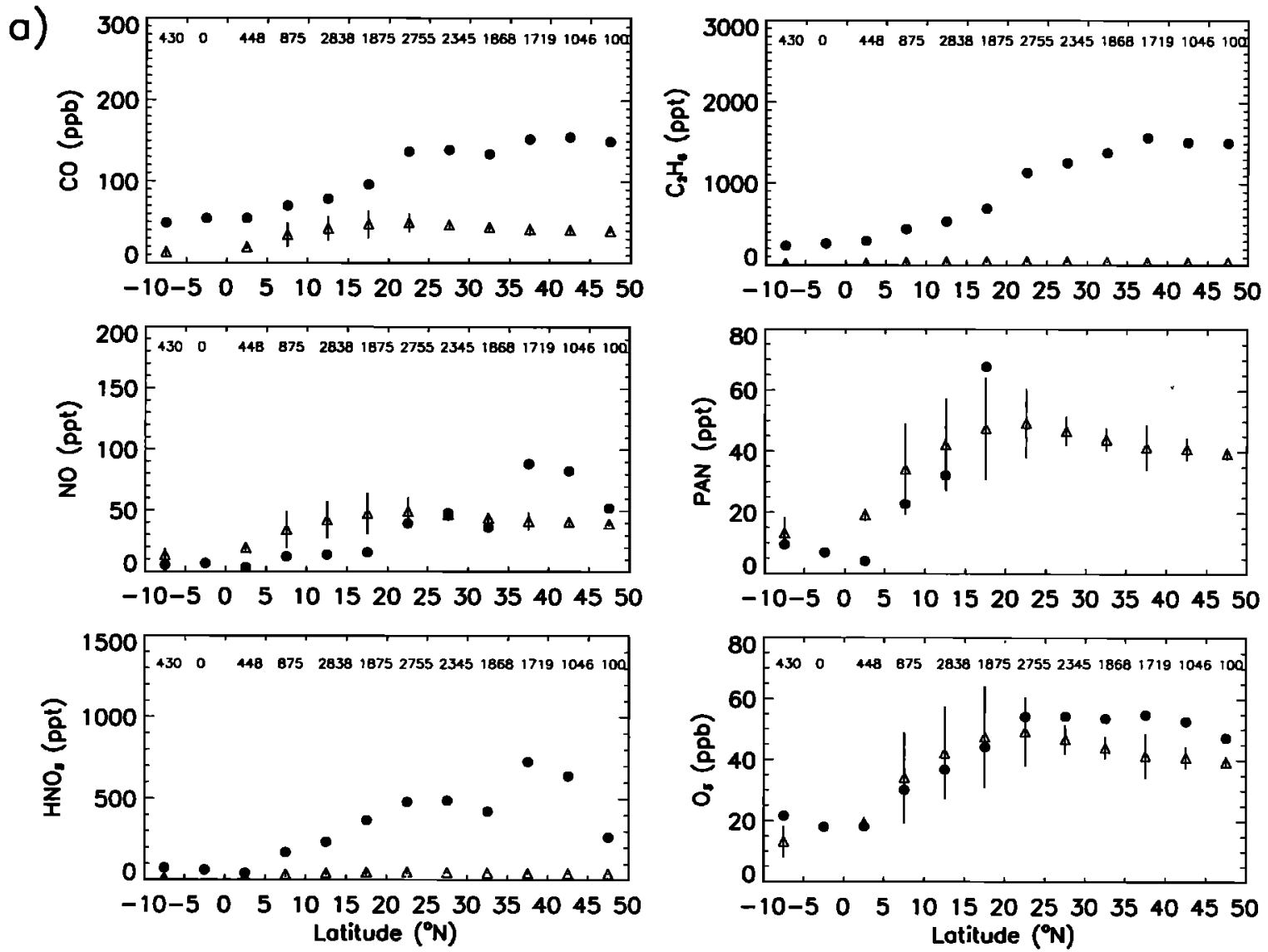

Figure 3. Comparison of PEM-West B aircraft observations (triangles) with model concentrations (solid circles) as function of latitude in the (a) lower troposphere (0-6 km) and (b) upper troposphere (6-12 km). Observed concentrations include data from all flights and have been averaged over $5^{\circ}$ latitude bands; model results are averaged over $5^{\circ}$ latitude bands and over longitude bins corresponding to those of observations for the days of the flights. (c) Comparison of PEM-West B aircraft observations (triangles) with model concentrations (solid circles) as function of longitude in the lower troposphere (0-6 km) north of $25^{\circ} \mathrm{N}$ of latitude. Sampling of observed and modeled values is done in the same way as described in Figures $3 \mathrm{a}$ and $3 \mathrm{~b}$. The number of individual observations used in obtaining mean values for each bin is indicated in insets in the plot.

the upper troposphere $(6-12 \mathrm{~km})$ (Figure 3b). Longitudinal variation is shown for the lower troposphere for latitudes higher than $25^{\circ} \mathrm{N}$ (Figure 3c) where the continental outflow is maximum [Blake et al., 1997; Talbot et al., 1997]. There is little longitudinal variation in the upper troposphere, so those results are not shown. We also compared vertical profiles collected during each flight with daily mean values sampled in the model for the corresponding day and location of the flight. Two examples are given in Figure 4 which shows vertical profiles of modeled and observed concentrations of selected species $\left(\mathrm{O}_{3}, \mathrm{CO}, \mathrm{C}_{2} \mathrm{H}_{6}, \mathrm{NO}, \mathrm{PAN}, \mathrm{HNO}_{3}\right)$ for flight 17 (which took place over the Sea of Japan in the region impacted by continental outflow) and for flight 7 (which took place between the equator and $25^{\circ} \mathrm{N}$ ) (see Figure 1).

Observed concentrations of $\mathrm{CO}$ and ethane increase with latitude at all altitudes (Figures $3 a$ and $3 b$ ) and decline slightly from west to east (Figure 3c) due to dilution of the Asian outflow. The enhancements of $\mathrm{CO}$ and ethane are strongest in the lower troposphere north of $25^{\circ} \mathrm{N}$, where Asian outflow is most active [Blake et al., 1997; Talbot et al.,
1997]. The model underestimates $C O$ and ethane levels but it reproduces well the latitudinal and longitudinal gradients, including the enhancement due to continental outflow. The large underestimate of ethane in the lower troposphere north of $30^{\circ} \mathrm{N}$ suggests an underestimate of high-latitude sources from natural gas exploitation. The general underestimate of $\mathrm{CO}$ in our model has been discussed in section 2, but could also reflect here a regional underestimate of $\mathrm{CO}$ sources from biomass burning and wood fuel as discussed in section 4.2. The model reproduces well the coarse vertical structure of $\mathrm{CO}$, for example the strong increase observed below $6 \mathrm{~km}$ during flight 17 (Figure 4a). It cannot capture fine layers of the extremely high CO levels (up to $300 \mathrm{ppb}$ ) observed during that flight, if only because of insufficient vertical and horizontal resolution.

Relatively high NO concentrations are observed in the Asian continental outflow at $15^{\circ}-40^{\circ} \mathrm{N}$. Some anomalously high NO concentrations are observed at $20^{\circ} \mathrm{N}$ and south of the equator in the upper troposphere. Koike et al. [1997] attributed the high levels around $25^{\circ} \mathrm{N}$ to fresh aircraft 
b)

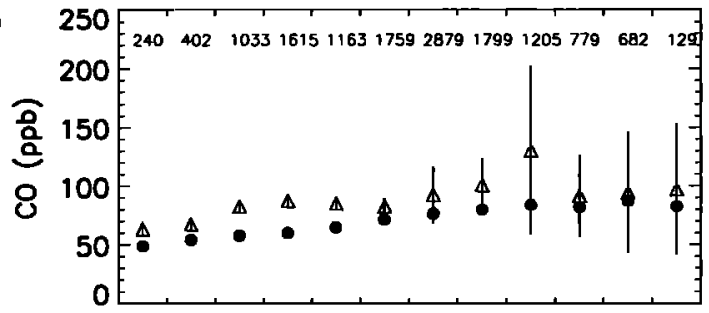

-10-5 O 5101520253035404550

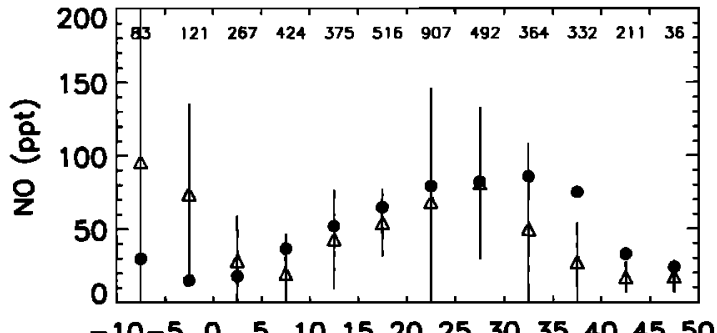

-10-5 $0 \quad 5 \quad 101520253035404550$

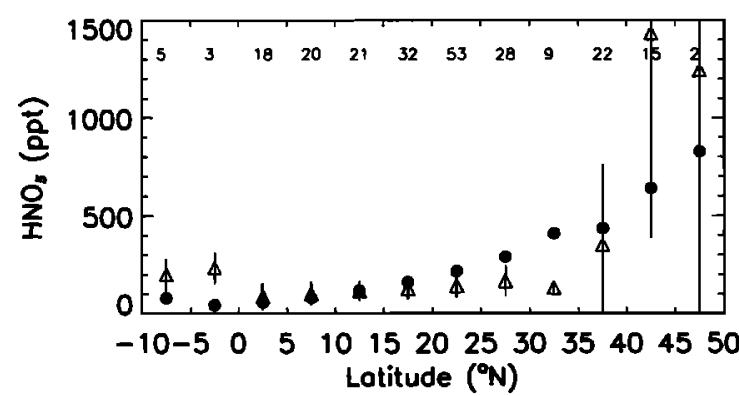

c)

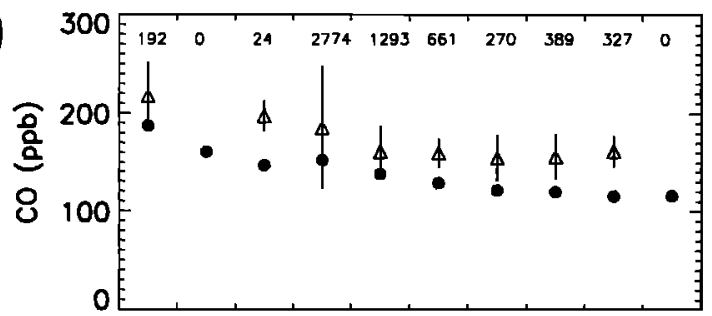

120125130135140145150155160165170

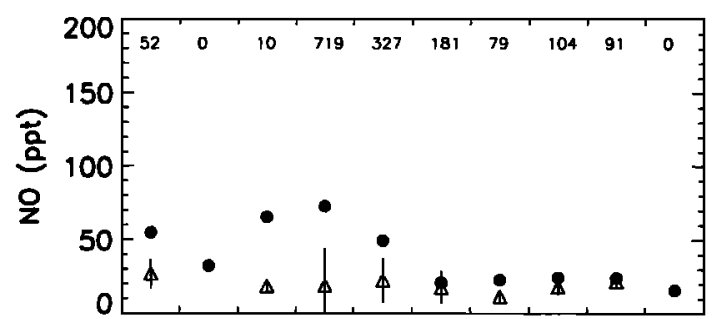

120125130135140145150155160165170

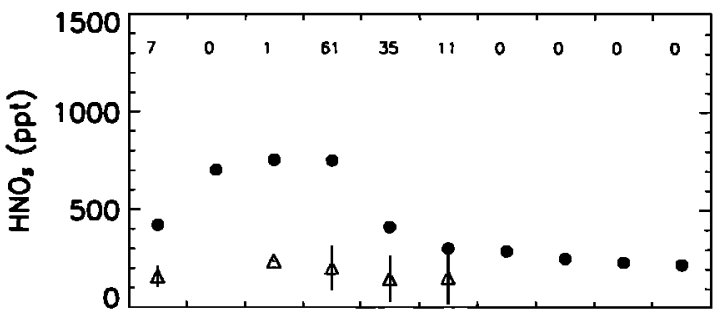

120125130135140145150155160165170 Longitude $\left({ }^{\circ} \mathrm{E}\right)$

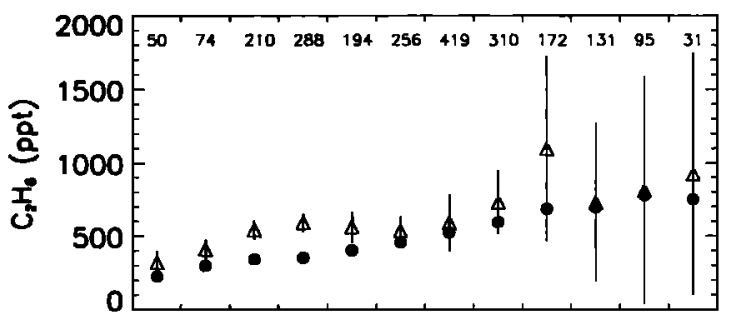

-10-5 0 5101520253035404550
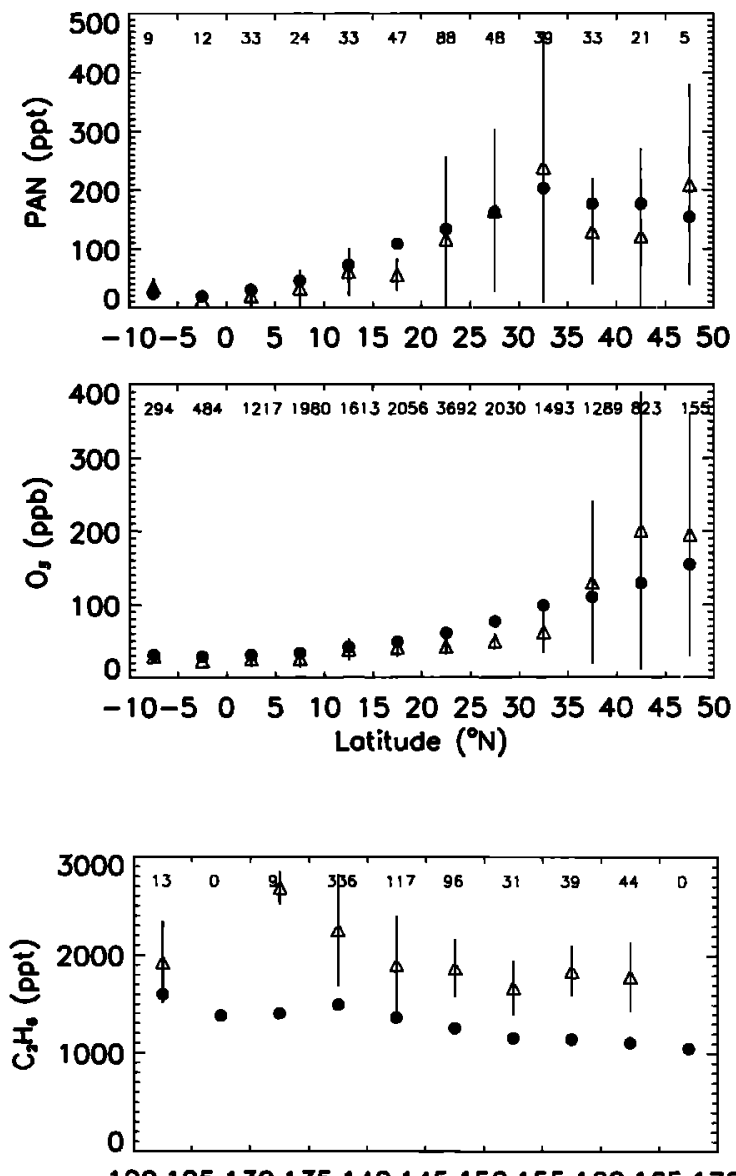

120125130135140145150155160165170

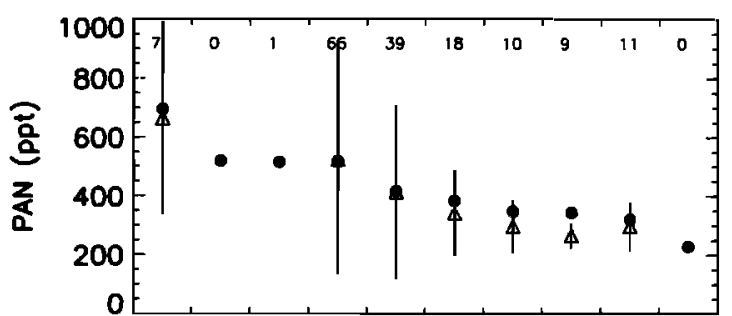

120125130135140145150155160165170

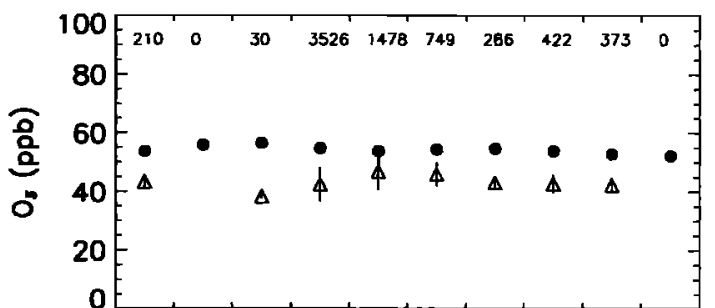

120125130135140145150155160165170 Longitude ( $\left.{ }^{\circ} \mathrm{E}\right)$

Figure 3. (continued) 


\section{a) Flight 17}
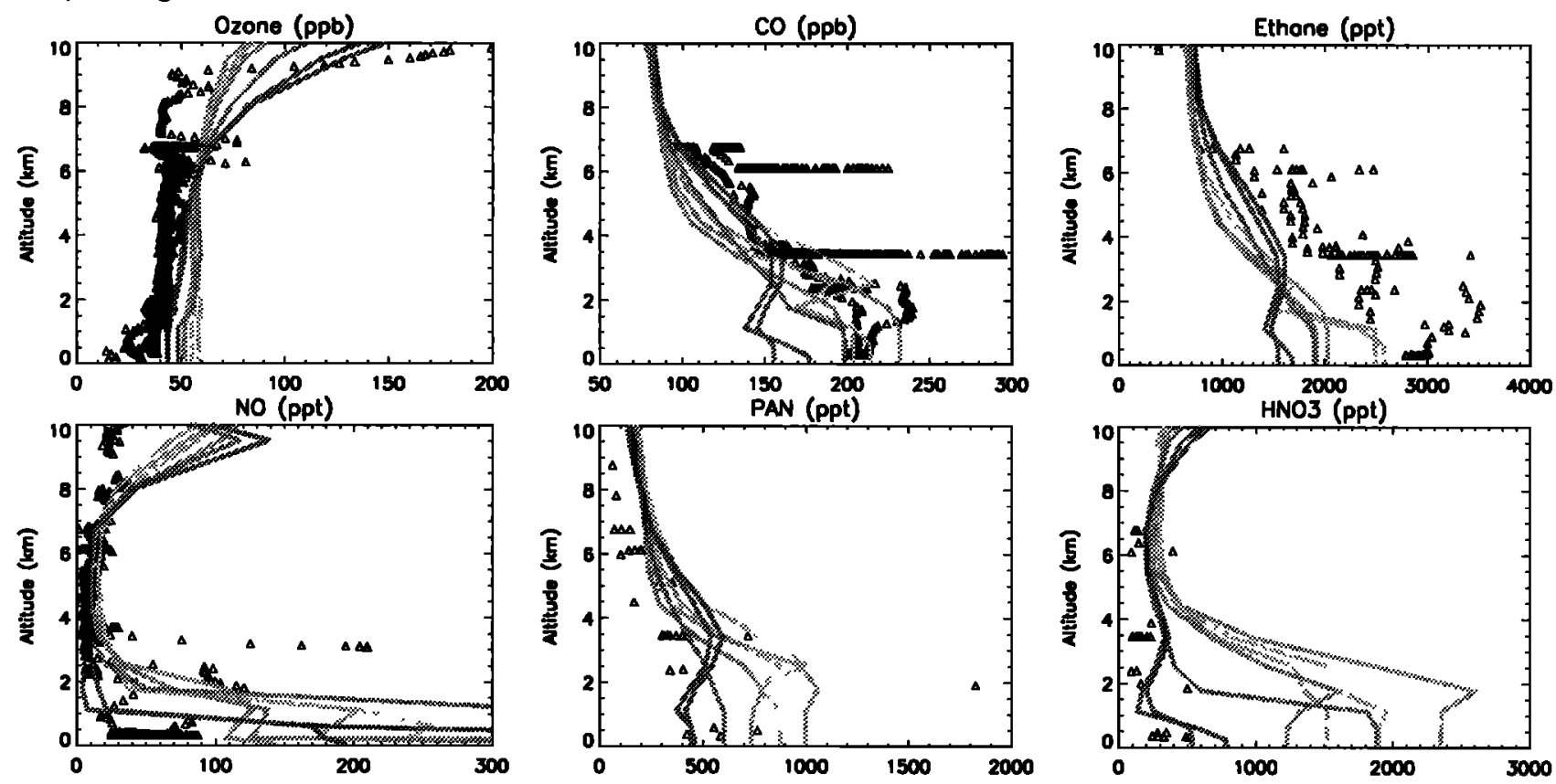

b) Flight 7
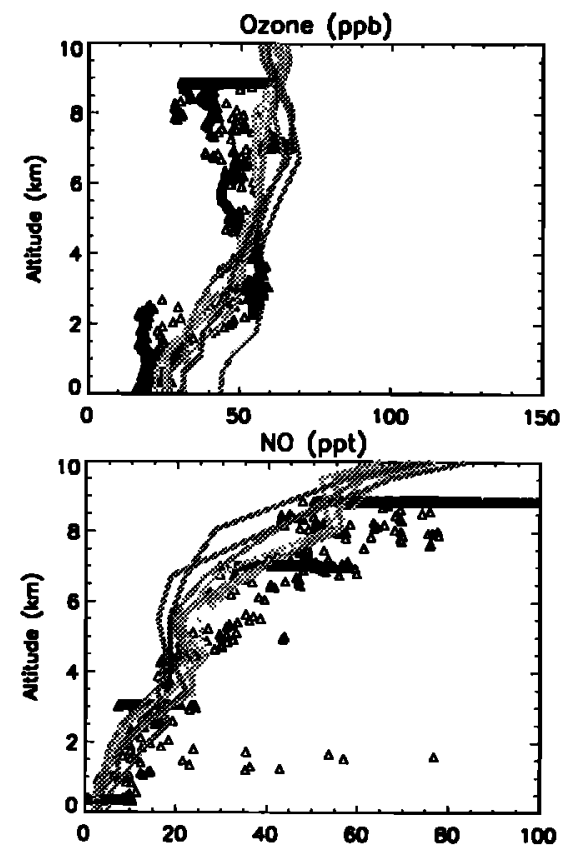
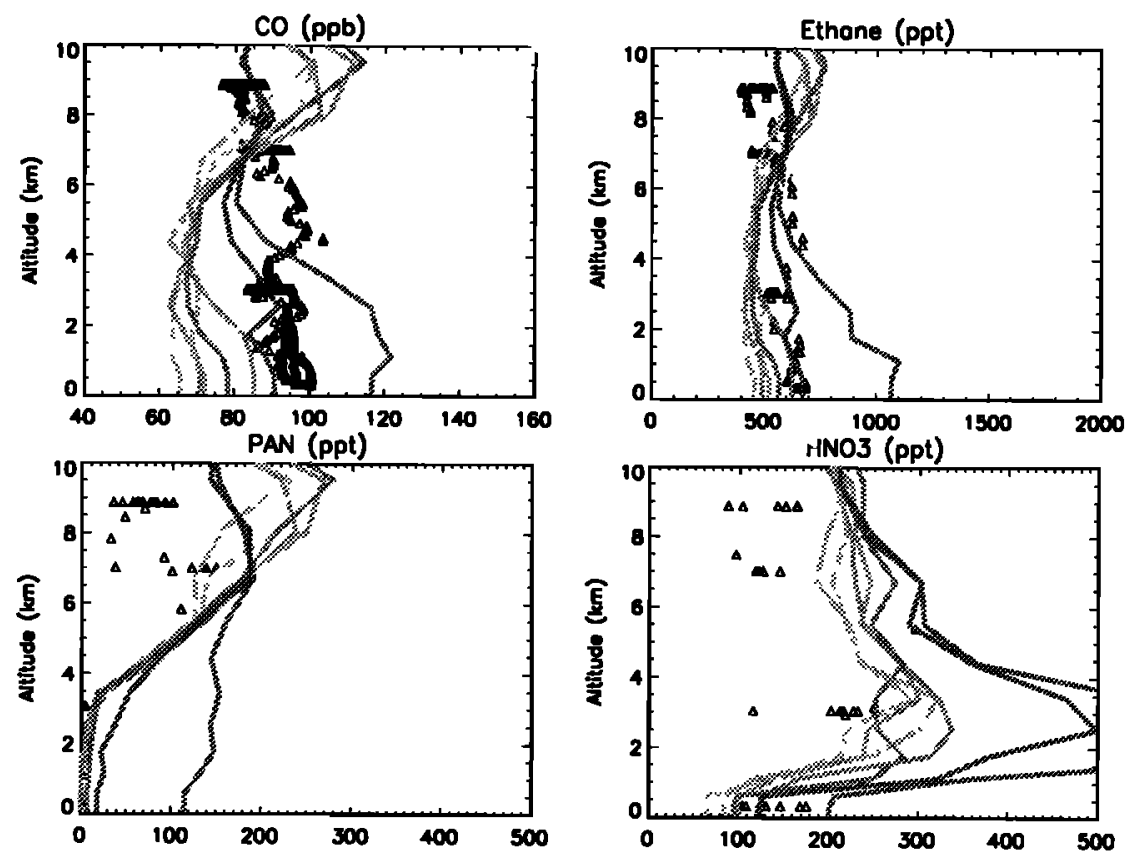

Figure 4. Comparison of model results with PEM-West B aircraft observations on (a) flight 17 and (b) flight 7 (see flight tracks in Figure 1). Triangle are observations. Grey lines are model results for the different grid squares sampled along the flight track. The model values are 24-hour averages (daytime averages for NO) for the days of the flights.

exhaust from the air traffic corridor between Japan and Southeast Asia. Levels as high as $900 \mathrm{ppt}$ were observed in the southern tropics during PEM-West $B$ and appear related to lightning activity [Kawakami et al., 1997; Crawford et al., 1997]. The model reproduces the general increase of NO with latitude (Figures $3 a$ and $3 b$ ) but overestimates NO levels in the lower troposphere especially north of $35^{\circ} \mathrm{N}$
(Figures 3a and 3c). Observations north of $35^{\circ} \mathrm{N}$ are for the narrow corridor between Japan and China (Figure 1) which is not geographically resolved in the model because of the $4^{\circ}$ by $5^{\circ}$ horizontal resolution. The model underestimates NO in the southern tropics, indicating a possible underestimate of lightning $\mathrm{NO}_{x}$ emissions in the model for that region. Simulated vertical profiles of NO for these latitudes show 

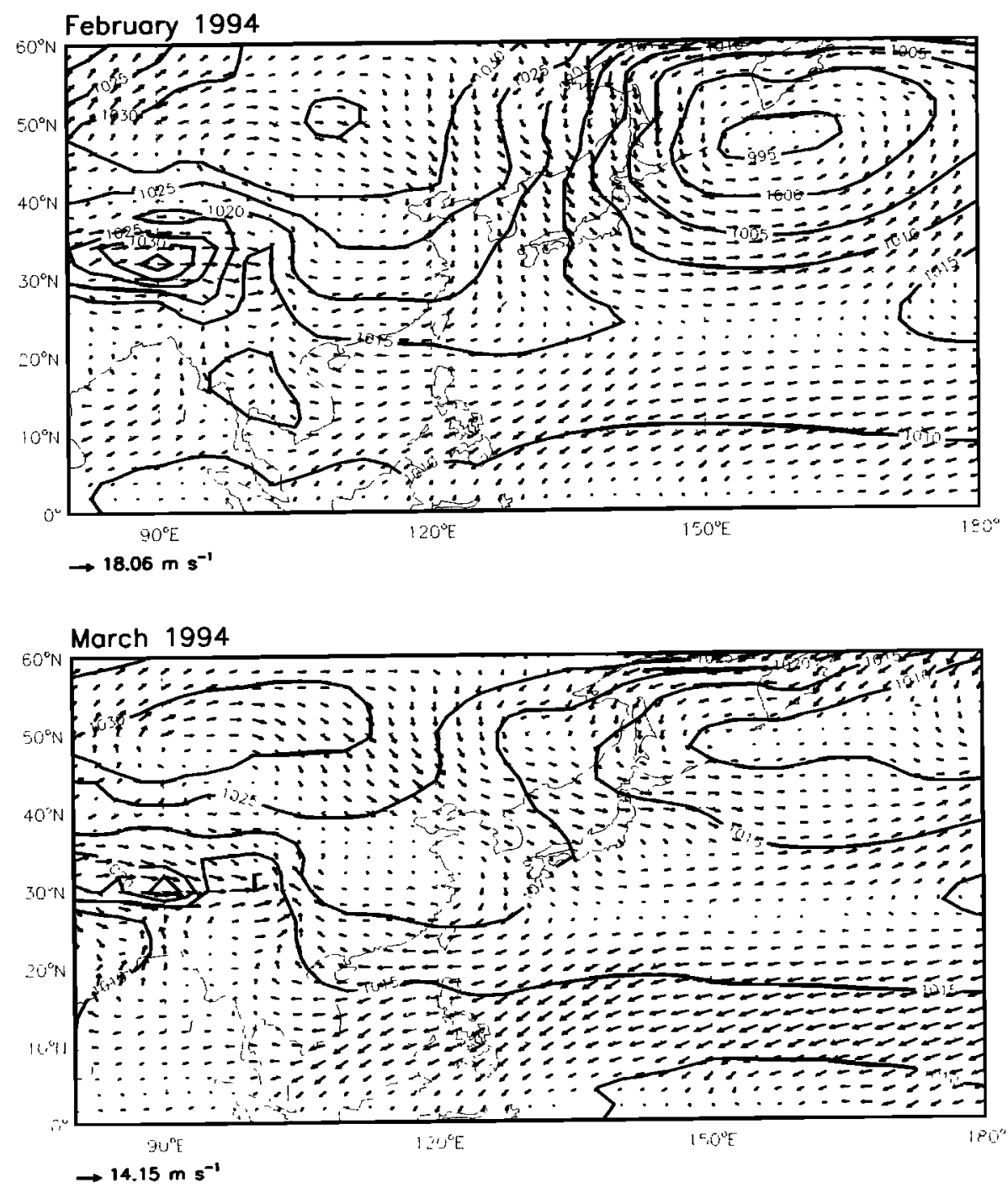

Figure 5. Monthly mean GEOS sea level pressures (hPa) for February and March 1994 and corresponding wind vectors at $250 \mathrm{~m}$ above the surface.

an increase of NO concentrations up to $100 \mathrm{ppt}$ in the upper troposphere but never reach the highest observed values. The observed PAN mixing ratios show strong gradients with latitude and longitude similar to $\mathrm{CO}$ and hydrocarbons that are well captured by the model. $\mathrm{HNO}_{3}$ concentrations are greatly overestimated, especially north of $25^{\circ} \mathrm{N}$ in the lower troposphere (Figures 3a and 3c). A possible explanation is partioning of nitrate into the aerosols which the model does not resolve. This effect could be especially important in Asian outflow because of high concentrations of alkaline soil dust aerosol [Chen et al., 1997; Zhang and Carmichael, 1999].

The model reproduces well the observed ozone mixing ratios with the exception of an overestimate of $10-15 \mathrm{ppb}$ in the lower troposphere north of $25^{\circ} \mathrm{N}$. This could reflect a too strong stratospheric input in that season in our model [Bey et al., this issue]. Another possibility is heterogeneous reaction of ozone on dust, which we do not account for: Zhang and Carmichael [1999] and Dentener et al. [1996] have proposed that heterogeneous reaction of ozone on dust could provide an important ozone sink in Asian continental plumes ( 10 to $40 \%$ ) but there is so far no identified mechanism or experimental evidence for this reaction.

\section{Pathways for the Export of Pollution From Asia}

\subsection{Meteorological Setting in February-March}

Early spring in Asia corresponds to the period of transition between the winter and summer monsoons. During winter the major meteorological features are the Siberian High over Mongolia/Siberia and the Aleutian Low over the Pacific Ocean (Figure 5). The Siberian High produces in the mean a strong northerly flow in the boundary layer along the Pacific rim (Figure 5). When the flow reaches Southeast Asia, it meets a marine tropical air mass from the Pacific carried by the northeastern trade winds [Watts, 1969]. The meteorological situation over eastern China in winter-early spring is also characterized by the frequent passages of strong cold fronts which move southward across northern China and 
a) $\mathrm{CO}$ onthropogenic emissions $\left(10^{-12}\right.$ moles $\left.\mathrm{cm}^{-2} \mathrm{~s}^{-1}\right)$

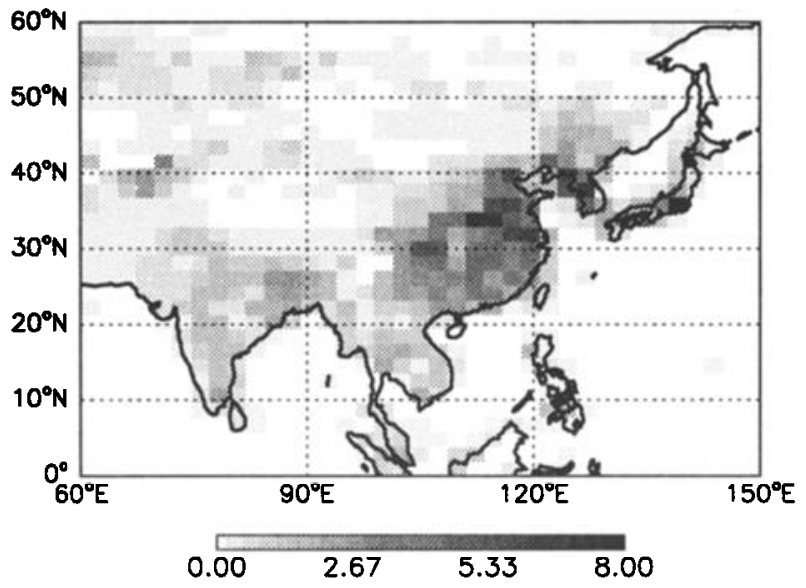

b) CO biomass burning emissions $\left(10^{-12}\right.$ moles $\left.\mathrm{cm}^{-2} \mathrm{~s}^{-1}\right)$

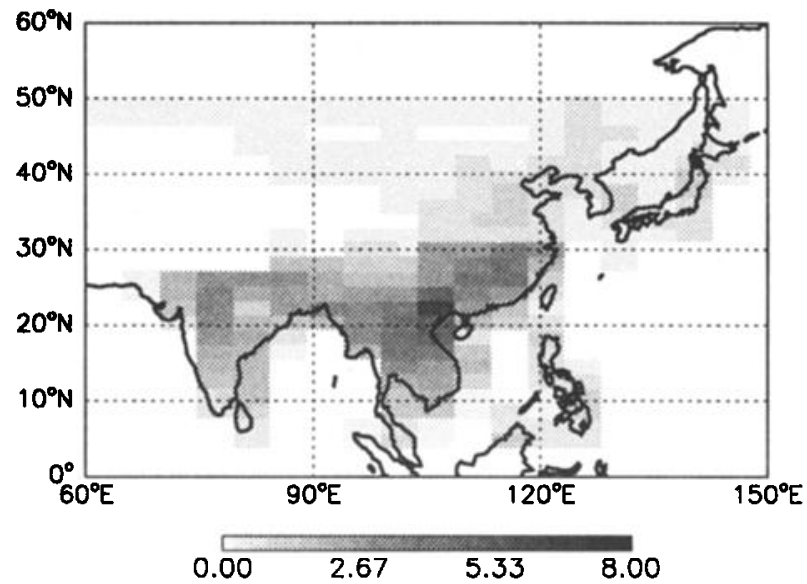

Figure 6. Carbon monoxide emissions in Asia in February-March 1994 from (a) anthropogenic activities (fossil and wood fuels) and (b) biomass burning.

Korea. Cold fronts in East Asia are known to be stronger than in other parts of the world (in term of wind speed and variation in surface temperature and pressure) because of the presence of the Tibetan Plateau which limits the southward movement of the polar air and thus leads to the formation of the very strong high pressure system over Siberia [Yihui et al., 1994]. By March the Siberian High weakens, while the Pacific high-pressure system is building up (Figure 5). As a result, the strength of the winter monsoon winds and the frequency of occurrence of the cold south moving surges o) Asian co horizontal flux (1000-150 hPa)

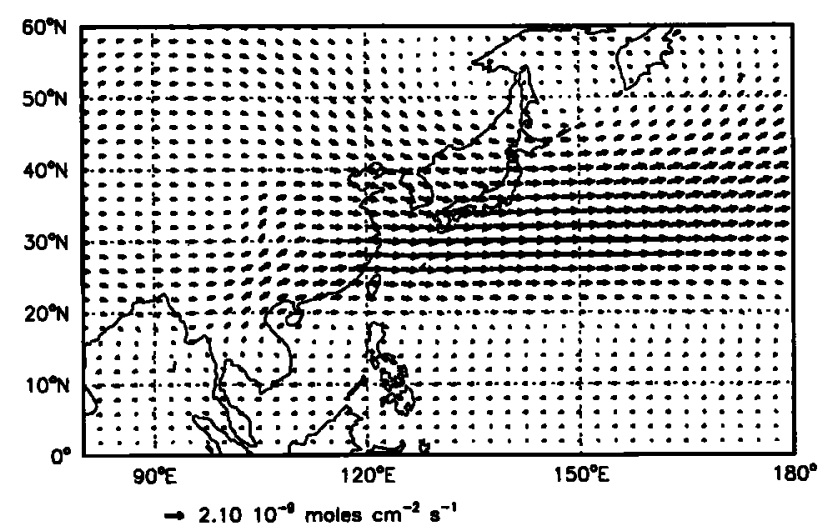

c) Asion anthropogenic co horizontal flux $(0-3 \mathrm{~km})$

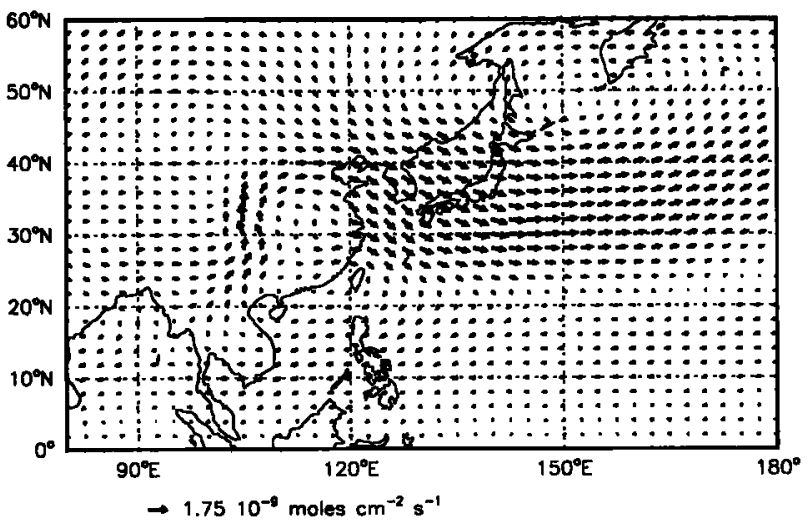

b) Asian $\mathrm{CO}$ horizontol flux $(0-3 \mathrm{Km})$

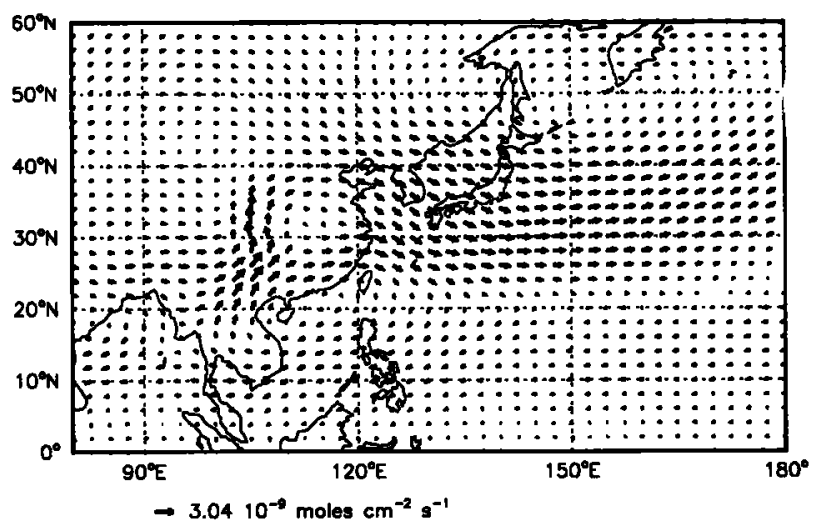

d) Asian biomoss burning $\mathrm{CO}$ horizontal flux $(0-3 \mathrm{Km})$

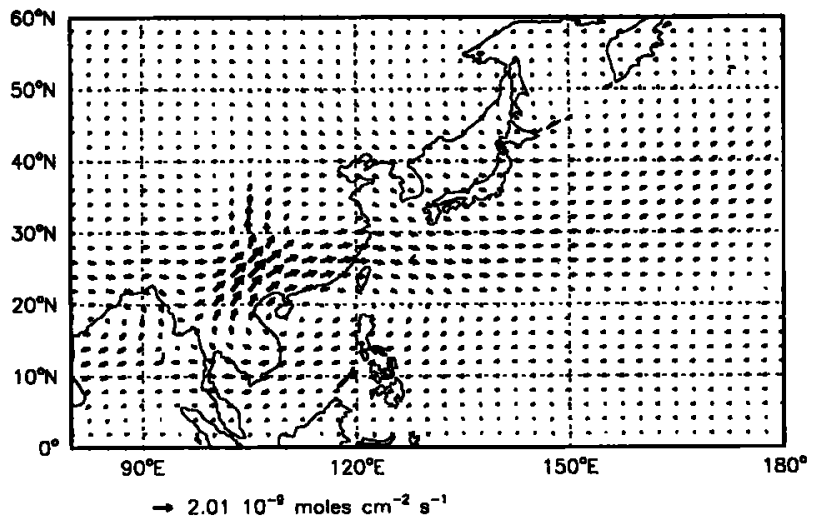

Figure 7. (a) Horizontal flux of Asian $\mathrm{CO}$ in the troposphere (1000-150 hPa column). (b) Horizontal flux of Asian CO in the boundary layer (surface-3 km column). (c) Same as Figure $7 \mathrm{~b}$ but only for anthropogenic Asian $\mathrm{CO}$. (d) same as Figure $7 \mathrm{~b}$ but only for biomass burning Asian $\mathrm{CO}$. The fluxes are averages for February-March 1994. "Asian CO" refers to CO emitted within our Asia region (Figure 2). Anthropogenic and biomass burning contributions are separated using tagged tracers. 
decrease, while incursions of warmer and tropical air from the south become more frequent. The warming leads to more frequent development of convective thunderstorms, especially in Southeast Asia [Nieuwolt, 1977]. Figure 5 shows the presence of a convergence zone over central China where air masses from the north, driven by monsoon winds, encounter oceanic air masses coming from the south. As expected, the convergence zone becomes more apparent as the winter monsoon weakens and the regime of summer monsoon slowly starts to establish. As will be discussed later, this convergence zone plays an important role in the springtime export of pollution from the Asian continent. In contrast to the lower troposphere, winds in the free troposphere (not shown here) show little variability during the winter-spring transition. Strong westerlies are the prevailing meteorological pattern at altitudes above $4 \mathrm{~km}$ and latitudes above $20^{\circ} \mathrm{N}$.

\subsection{Export Pathways for Carbon Monoxide}

Figures $6 \mathrm{a}$ and $6 \mathrm{~b}$ show the distribution of $\mathrm{CO}$ emissions in Asia in February-March from anthropogenic activities and biomass burning, respectively. Anthropogenic emissions include fuel combustion (fossil and wood), industrial activities, plus minor sources from other industrial activities such as steel manufacturing. Biomass burning emissions include sources from forest wildfires, deforestation, savanna burning, slash-and-burn agriculture, and agricultural waste burning. Anthropogenic emissions are largest in northeastern China. Spring is the dry season in Asia, and there is extensive biomass burning in Southeast Asia and India, mainly due to burning of agricultural waste (rice straw) and deforestation [Nguyen et al., 1994]. Our yearly inventories for $\mathrm{CO}$ emissions in Asia (for the geopolitical region shown Figure 2) include $113 \mathrm{Tg} \mathrm{CO} \mathrm{yr}^{-1}$ from fossil fuel combustion, $59 \mathrm{Tg} \mathrm{CO} \mathrm{yr}^{-1}$ from woodfuel burning, and $61 \mathrm{Tg} \mathrm{CO}$ $\mathrm{yr}^{-1}$ from biomass burning (concentrated in the 4-month period from January to April). Recent inventories suggest a higher $\mathrm{CO}$ source in Asia from biofuel combustion and biomass burning ( $165 \mathrm{Tg} \mathrm{CO} \mathrm{yr}^{-1}$ [Galanter et al., 2000; $R$. $M$. Yevich and J. A. Logan, personal communication, 2000]) than we used in our model $\left(120 \mathrm{Tg} \mathrm{CO} \mathrm{yr}^{-1}\right)$, and this could contribute to the $\mathrm{CO}$ model underestimate discussed in section 2. During February-March, Asian CO emissions from anthropogenic activities and biomass burning are of comparable magnitude $(28 \mathrm{Tg} \mathrm{CO})$ in our model.

Mean horizontal fluxes of Asian $\mathrm{CO}$ integrated over the tropospheric column (1000-150 hPa) and over the boundary layer (lowest $3.0 \mathrm{~km}$ ) are shown in Figures $7 \mathrm{a}$ and $7 \mathrm{~b}$, respectively. These fluxes were calculated from the tagged $\mathrm{CO}$ tracer simulation (section 2) for $\mathrm{CO}$ emitted in Asia (Figure a) Asian CO vertical flux at $3 \mathrm{~km}$

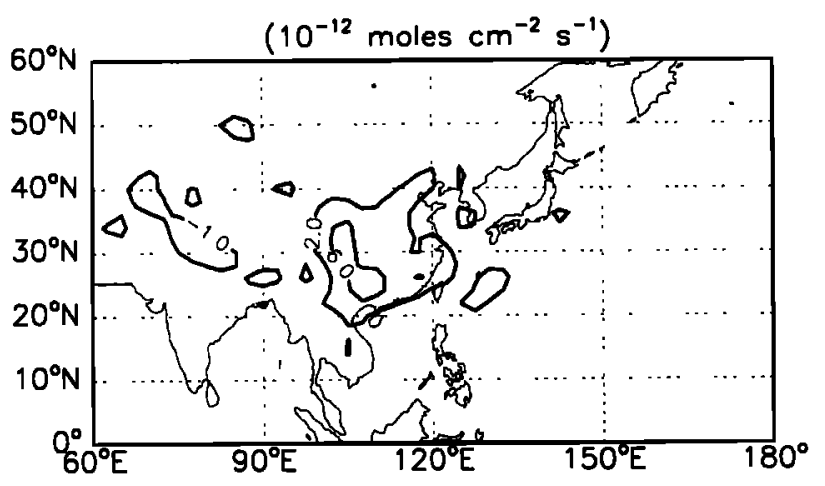

c) Asion anthropogenic CO zonal flux at $140^{\circ} \mathrm{E}$

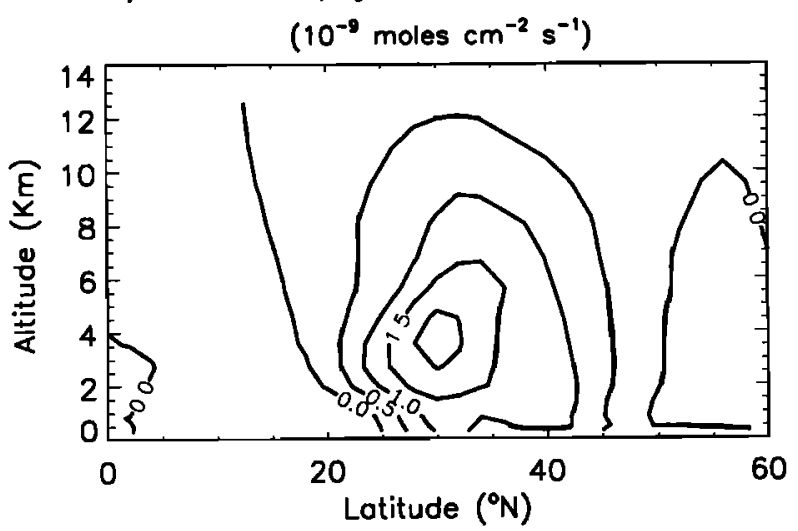

b) Asian $\mathrm{CO} z o n a l$ flux at $140^{\circ} \mathrm{E}$

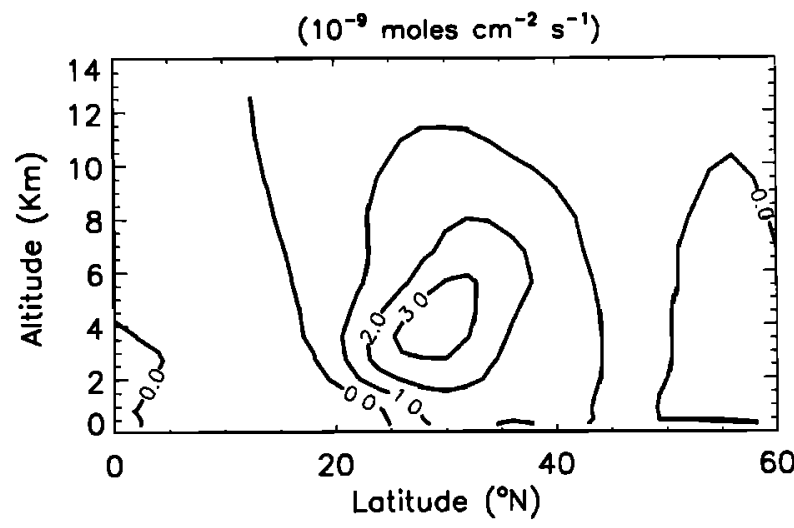

d) Asian biomoss burning $\mathrm{CO}$ zonal flux ot $140^{\circ} \mathrm{E}$ $\left(10^{-2}\right.$ moles $\left.\mathrm{cm}^{-2} \mathrm{~s}^{-1}\right)$

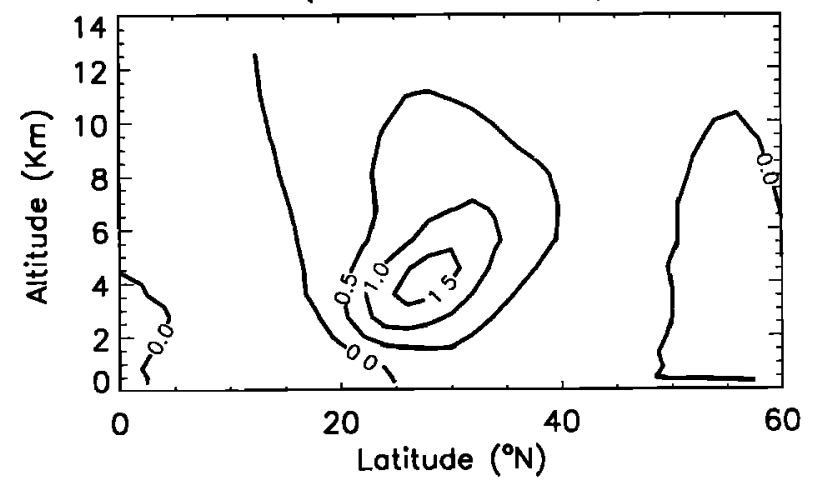

Figure 8. (a) Vertical flux of Asian $\mathrm{CO}$ at the top of the boundary layer $(3 \mathrm{~km})$. Positive fluxes are upward. (b) Zonal flux of Asian $\mathrm{CO}$ at $140^{\circ} \mathrm{E}$. Positive fluxes are eastward. (c) Same as Figure $8 \mathrm{~b}$ but only for anthropogenic Asian CO. (d) Same as Figure 8b but only for biomass burning Asian CO. Fluxes are averages for February-March 1994. 
(a)

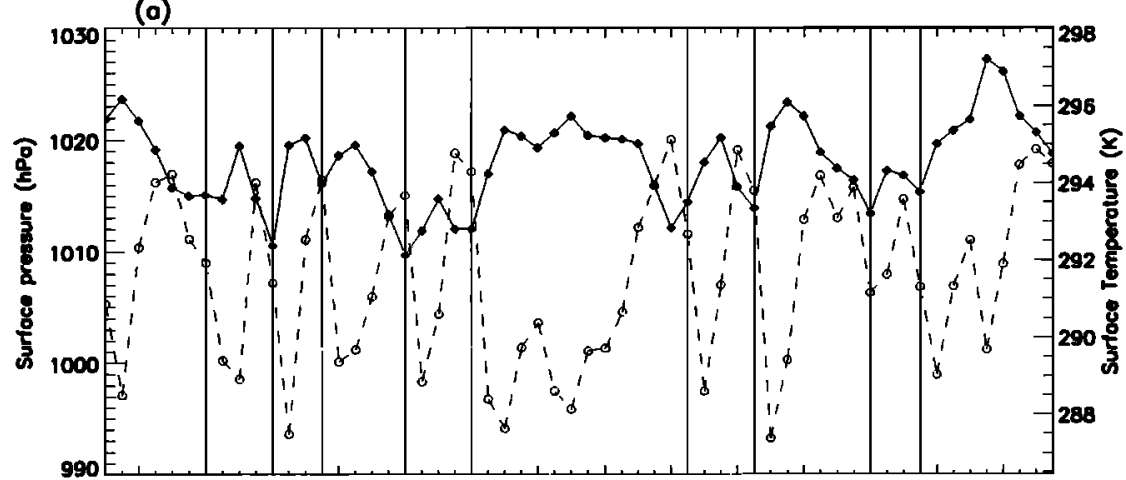

(b)

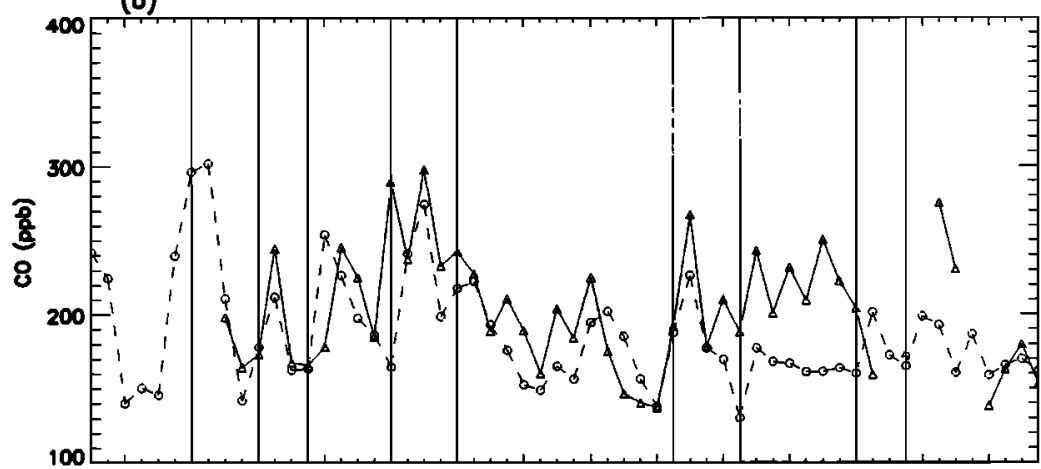

(c)

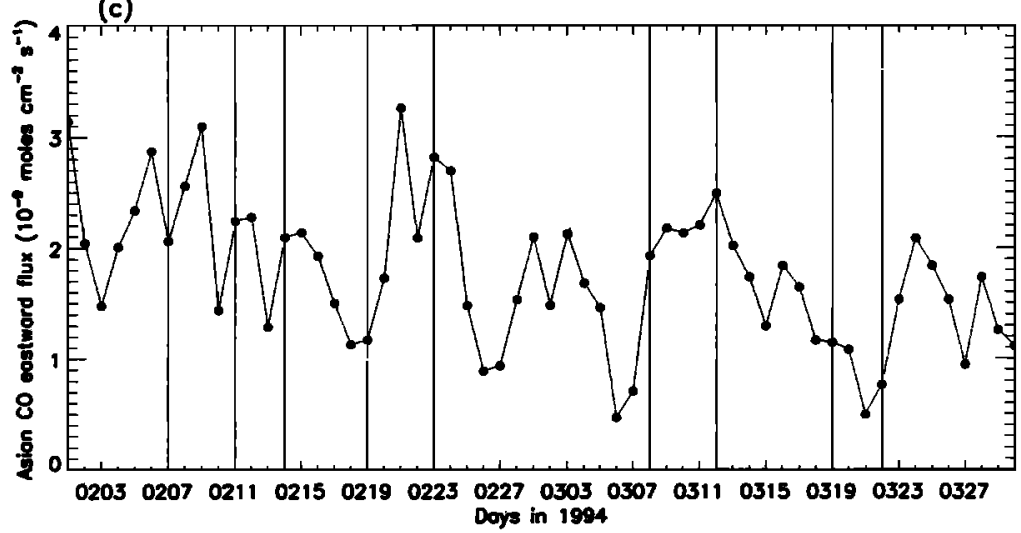

Figure 9. Time series of meteorological variables and $\mathrm{CO}$ concentrations for a site on the southern tip of Taiwan operated by Liu et al. [1997] in February-March 1994. (a) GEOS sea level surface pressure (solid line, left axis) and surface temperature (dashed line, right axis). (b) Observed CO concentrations (solid line) and corresponding model results (dashed line) obtained with the $2^{\circ} \times 2.5^{\circ}$ horizontal resolution version of the model. (c) Eastward fluxes of Asian $\mathrm{CO}\left(10^{-9}\right.$ moles $\left.\mathrm{cm}^{-2} \mathrm{~s}^{-1}\right)$ through a wall located at $140^{\circ} \mathrm{E}$ between $20^{\circ}$ and $40^{\circ} \mathrm{N}$. Vertical lines mark the passage of cold fronts at the site as reported by Liu et al. [1997].

2) from anthropogenic activities and biomass burning. The main export pathway for Asian pollution is to the Pacific in the westerly flow north of $25^{\circ} \mathrm{N}$. Figure 5 shows northerly surface winds along the coast of China that reach southern latitudes but the winds shift to westerly above $1 \mathrm{~km}$ altitude. Maps of horizontal $\mathrm{CO}$ fluxes at individual levels indicate that little mass is carried in the northerly surface flow, as is apparent from Figure $7 \mathrm{~b}$, and part of this flow is eventually recirculated over the continent by anticyclonic circulation over Southeast Asia. Figure 7 shows strong southwesterly CO fluxes over China from $20^{\circ} \mathrm{N}$ to $30^{\circ} \mathrm{N}$ which result from the colocation of high emissions with the convergence zone described previously (Section 4.1). This convergence results in an upward flux of $\mathrm{CO}$ (see Figure 8) which lifts the pollution above the boundary layer into the free troposphere where it is caught by the strong westerlies. We thus find that the strongest export flux of Asian $\mathrm{CO}$ to the western Pacific is at $4 \mathrm{~km}$ altitude (Figure 8b) even though the highest concentrations along the Pacific rim are found below $2 \mathrm{~km}$ altitude (Figure 4a).

We investigated separately the contributions of anthropogenic and biomass burning sources to the export of Asian $\mathrm{CO}$ to the western Pacific. Biomass bar ing $\mathrm{CO}$, mainly emitted in Southeast Asia, is transported toward the conver- 
gence zone where it is uplifted into the free troposphere and then carried by the westerlies. Little biomass burning $\mathrm{CO}$ is exported over the ocean in the boundary layer (Figure 8d). In contrast, $\mathrm{CO}$ from fossil fuel combustion, which is emitted at more northerly latitudes, shows substantial export in the boundary layer by the monsoon winds, especially at latitudes higher than $35^{\circ} \mathrm{N}$. Even for fossil fuel $\mathrm{CO}$, however, most of the export is in the lower free troposphere (Figure 8c). In our model, during February-March, deep convective events are largely restricted to Southeast Asia, and thus mainly contribute to export of biomass burning $\mathrm{CO}$. Large-scale convergence rather than convection is the principal driver for ventilation of Asian pollution from the boundary layer to the free troposphere in our model during February-March.

Our discussion so far has focused on monthly mean concentrations and fluxes. Examination of daily fields shows that the export of $\mathrm{CO}$ from the Asian continent is in fact episodic. The episodic export of pollution can be illustrated by ground-based observations during PEM-West B by Liu et al. [1997], who conducted continuous measurements of $\mathrm{CO}$ and ozone at the southern tip of Taiwan $\left(22^{\circ} \mathrm{N}, 122^{\circ} \mathrm{E}\right)$. Their measurements are shown in Figure 9, together with GEOS meteorological data for temperature and pressure at the site and corresponding model results for $\mathrm{CO}$. As discussed in section 4.1, the synoptic weather pattern in Asia in late winter-early spring is dominated by the passage of cold fronts, each cold front being followed by strong outbreaks of cold air masses. At the passage of each front, Liu et al. [1997] observed a shift of wind direction from north-northeasterly to south-southwesterly, bringing marine tropical air with low $\mathrm{CO}$ to the site. After the passage of the front, they observed a sharp increase of $\mathrm{CO}$ due to transport from the Asian continent. Frontal passages in the GEOS meteorological data, as diagnosed from pressure drops followed by temperature drops (Figure 9a), match the dates identified by Liu et al. [1997] i.e., February 6-7, 1112, 14-15, 19-20, 23-24, and March 7-8, 12-13, 19-20, 2223. The model reproduces well most of the events of high $\mathrm{CO}$ concentrations observed at the site, as shown in Figure $9 \mathrm{~b}$. In our model the passage of a cold front results most of the time in an increase of the CO vertical flux out of the boundary layer (due to lifting of warm air ahead of the cold front) followed by an increase in the eastward flux of $\mathrm{CO}$ to the western Pacific due to rapid transport by westerly winds in the free troposphere (Figure 9c).

Our successful simulation of the frontal events and associated CO changes seen in the Liu et al. [1997] observations confirms that frontal activity is a major pathway for export of Asian pollution to the Pacific Ocean. An example of this mechanism is shown in Figure 10 for the February 1015 time period. On February 10 and 13 we find in the model a strong increase of the $\mathrm{CO}$ vertical flux out of the boundary layer, due to the passage of two successive cold fronts traveling through China (note from Figure 9a that these fronts are observed at Taiwan 1 day later). This leads to export of $\mathrm{CO}$ from China and formation of an Asian pollution plume in the midtroposphere over the Pacific, as seen in Figure 10b. During the PEM-West B period, about
10 major events can be identified in our model simulation (Figure 9c). Our analysis is consistent with that of Yienger et al. [2000], who proposed that an important mechanism for the export of pollution from Asia is the development of low-pressure baroclinic systems over Asia.

\section{Contribution of Intercontinental Transport to Asian Outflow}

The chemical outflow from the Asian continent to the western Pacific includes contributions from other continents besides Asia. Figure 11 shows the total column concentrations of each tagged CO tracer for February-March 1994, and Table 1 summarizes their contributions to the total $\mathrm{CO}$ burden in the Northern Hemisphere and to the Asian outflow (defined as the flux through a wall located at $140^{\circ} \mathrm{E}$ between $20^{\circ}$ and $50^{\circ} \mathrm{N}$ ). We discuss here the contributions of different geopolitical source regions as those originating from direct $\mathrm{CO}$ emissions only.

The largest single contribution to the $\mathrm{CO}$ burden in the Northern Hemisphere is the background source from methane oxidation. Next in importance are anthropogenic emissions in Europe and Asia, and biomass burning in Africa, which are all three of similar magnitude even though the African biomass burning source $\left(255 \mathrm{Tg} \mathrm{CO} \mathrm{yr}^{-1}\right)$ is greater than the anthropogenic Asian source (172 $\mathrm{Tg} \mathrm{CO}$ $\mathrm{yr}^{-1}$ ) or European source $\left(141 \mathrm{Tg} \mathrm{CO} \mathrm{yr}{ }^{-1}\right)$. Because African $\mathrm{CO}$ is emitted in the tropics, its lifetime against oxidation by $\mathrm{OH}$ ( 39 days) is shorter than that of Asian or European CO (66 and 86 days, respectively, Table 1). We see from Table 1 that the Asian outflow includes major contributions from anthropogenic emissions in Asia (21\%) as well as Europe (15\%) and from biomass burning emissions in Asia (12\%) as well as Africa (11\%). European CO makes a relatively large contribution because of its accumulation at high latitudes in winter [Staudt et al., 2001]. Biomass burning in northern Africa occurs from November to March with a peak from December to February (as shown by the advanced very high resolution radiometer (AVHRR) fire counts), thus it contributes significantly to the Asian outflow in February-March.

Pollution sources from different continents have distinct latitudinal signatures in their contributions to Asian outflow, as illustrated in Figure 12. In this figure each component has been sampled in the model as described in section 3, i.e. along the PEM-West $B$ flight tracks, and thus the total CO versus latitude shown in Figure 12 is similar to the one shown in Figure 3. In the lower troposphere, anthropogenic $\mathrm{CO}$ dominates over biomass burning $\mathrm{CO}$, while both categories are important in the upper troposphere. We find that Asian biomass burning contributes significantly to the total $\mathrm{CO}$ observed in the Asian outflow, especially south of $25^{\circ} \mathrm{N}$ and in the lower troposphere. This result is supported by observations of hydrocarbons and halocarbons from PEM West B. Blake et al. [1997] reported that polluted air masses sampled below $6 \mathrm{~km}$ presented a strong signature from fossil fuel combustion north of $25^{\circ} \mathrm{N}$ while thoses encountered south of $25^{\circ} \mathrm{N}$ were more characteristic of biomass burning 
a) CO vertical fluxes at $3 \mathrm{~km}(700 \mathrm{mb})$
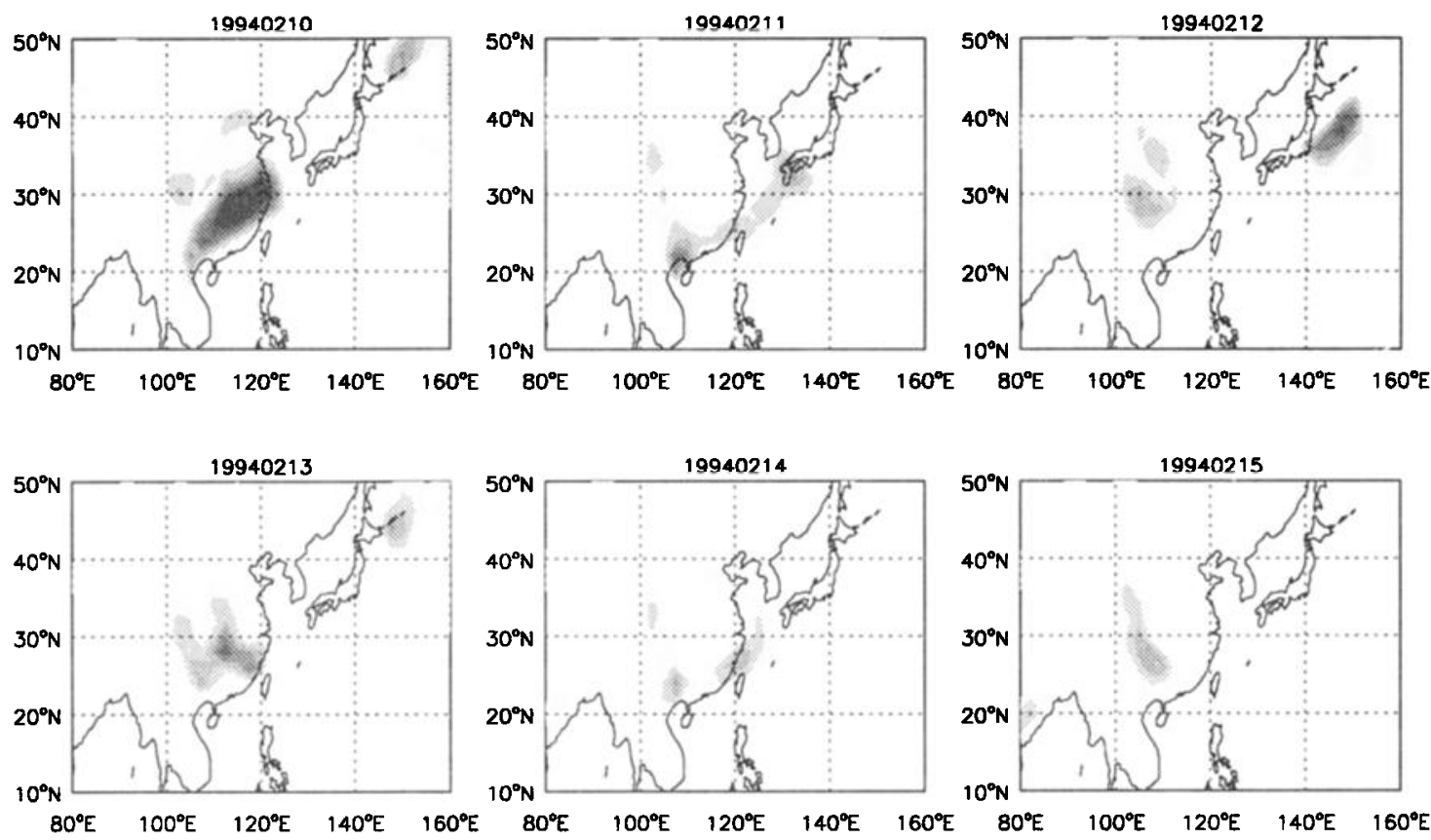

b) $\mathrm{CO}(\mathrm{ppb})$ at $4.5 \mathrm{~km}(580 \mathrm{mb})$
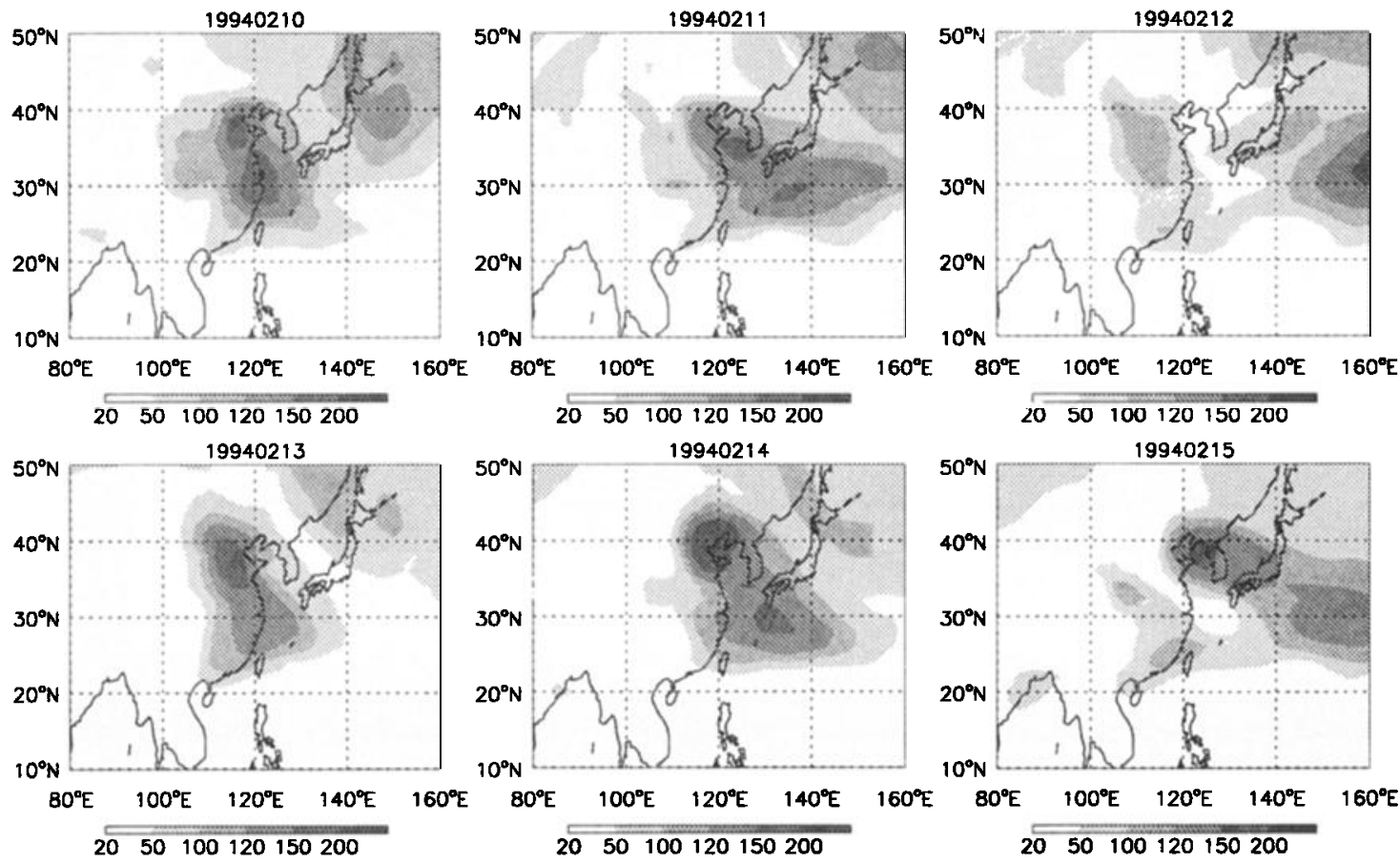

Figure 10. (a) Time series of $\mathrm{CO}$ vertical flux (moles $\mathrm{cm}^{-2} \mathrm{~s}^{-1}$ ) through the $3 \mathrm{~km}$ surface in the model. Shaded areas represent upward vertical $\mathrm{CO}$ fluxes. (b) Time series of $\mathrm{CO}$ concentrations (ppb) at 4.5 $\mathrm{km}$ altitude. Values are 24-hour average model results for individual days over the February 10-15, 1994 period.

sources. Note also that our definition of anthropogenic emissions includes woodfuel combustion, which accounts for about one third of anthropogenic emissions of $\mathrm{CO}$ in Asia. Such a source would have a biomass burning chemical signature in the observations. In the upper troposphere south of $25^{\circ} \mathrm{N}$ we find that African biomass burning is the single most important contributor to Asian outflow of $\mathrm{CO}$ The contribution from European sources to Asian outflow increases strongly with latitude and dominates over Asian sources north of $40^{\circ} \mathrm{N}$. This result reflects in large part the wintertime accumulation of European $\mathrm{CO}$ in the Arctic as noted previously. 

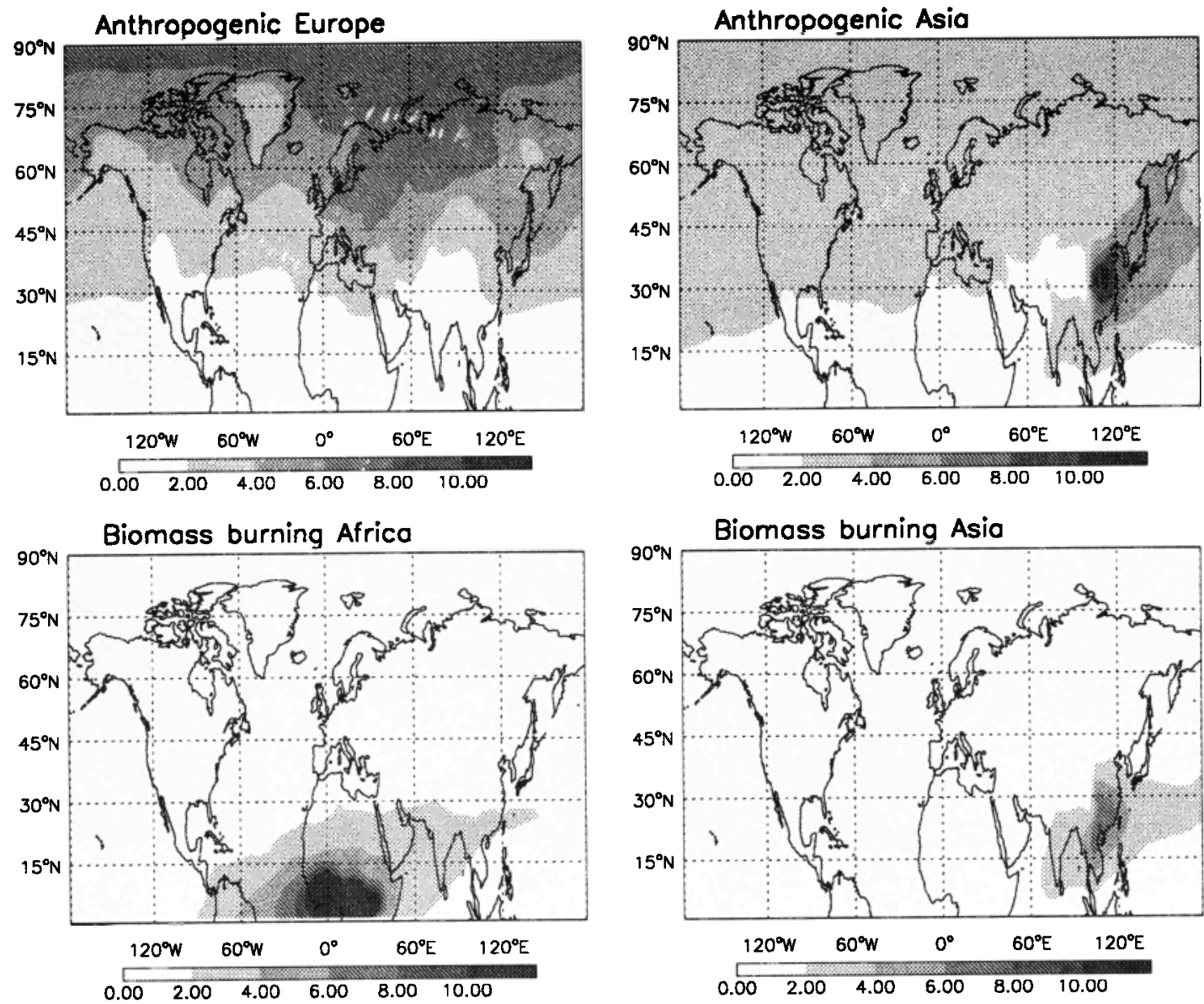

Figure 11. Carbon monoxide columns $\left(10^{17}\right.$ molecules $\left.\mathrm{cm}^{-2}\right)$ contributed by anthropogenic emissions from Asia and Europe, and biomass burning in Asia and Africa. Geopolitical source regions are given in Figure 2. Values are average model results for February-March 1994.

Table 1. Contributions From Different Source Regions to Asian Outflow of CO

\begin{tabular}{lrrrr}
\hline & \multicolumn{1}{c}{ Sources } & Northern Hemisphere Burden & Lifetime & Asian Outflow Flux \\
\hline Total CO & $2241(389)$ & $231(100 \%)$ & 56 & $45.2(100 \%)$ \\
Anthropogenic emissions & & $21(9 \%)$ & 75 & $4.0(9 \%)$ \\
$\quad$ North America & $95(15.4)$ & $30(13 \%)$ & 86 & $6.7(15 \%)$ \\
Europe & $141(22.8)$ & $30(13 \%)$ & 66 & $9.4(21 \%)$ \\
Asia & $172(27.8)$ & $10(4.5 \%)$ & 56 & $1.9(4 \%)$ \\
Other & $113(18.3)$ & $8(3.5 \%)$ & 56 & $0.9(2 \%)$ \\
Biomass burning emissions & & $28(12 \%)$ & 39 & $4.9(11 \%)$ \\
$\quad$ South America & $123(22.8)$ & $15(6.5 \%)$ & 50 & $5.3(12 \%)$ \\
Africa & $255(55.4)$ & $5(2.0 \%)$ & 72 & $0.8(2 \%)$ \\
Asia & $61(29.7)$ & $84(36.5 \%)$ & 55 & $11.3(25 \%)$ \\
Other & $82(7.8)$ & & & \\
Chemical production & $1170(189)$ & &
\end{tabular}

Geopolitical source regions are as given in Figure 2. Sources of $\mathrm{CO}$ are annual means for $1994 \mathrm{in} \mathrm{Tg} \mathrm{CO} \mathrm{yr}^{-1}$. (Values for February-March are given in parentheses in units of Tg CO.) Northern Hemispheric burdens of CO contributed by individual sources are model averages for February-March 1994 and are given in Tg CO. Lifetime in February-March 1994 for CO originating from each source is given in days. The Asian outflow flux is defined as the eastward flux $\left(10^{-9}\right.$ moles cm $\left.\mathrm{cm}^{-2} \mathrm{~s}^{-1}\right)$ integrated for the tropospheric column through a wall located at $140^{\circ} \mathrm{E}$ between $20^{\circ}$ and $50^{\circ} \mathrm{N}$; values are model averages for February-March 1994. "Chemical production" refers to the source of CO from methane oxidation ( $\left.945 \mathrm{Tg} \mathrm{CO} \mathrm{yr}^{-1}\right)$ and isoprene oxidation $\left(225 \mathrm{Tg} \mathrm{CO} \mathrm{yr}^{-1}\right)$. The small source of CO from oxidation of other hydrocarbons is not included in this budget. 

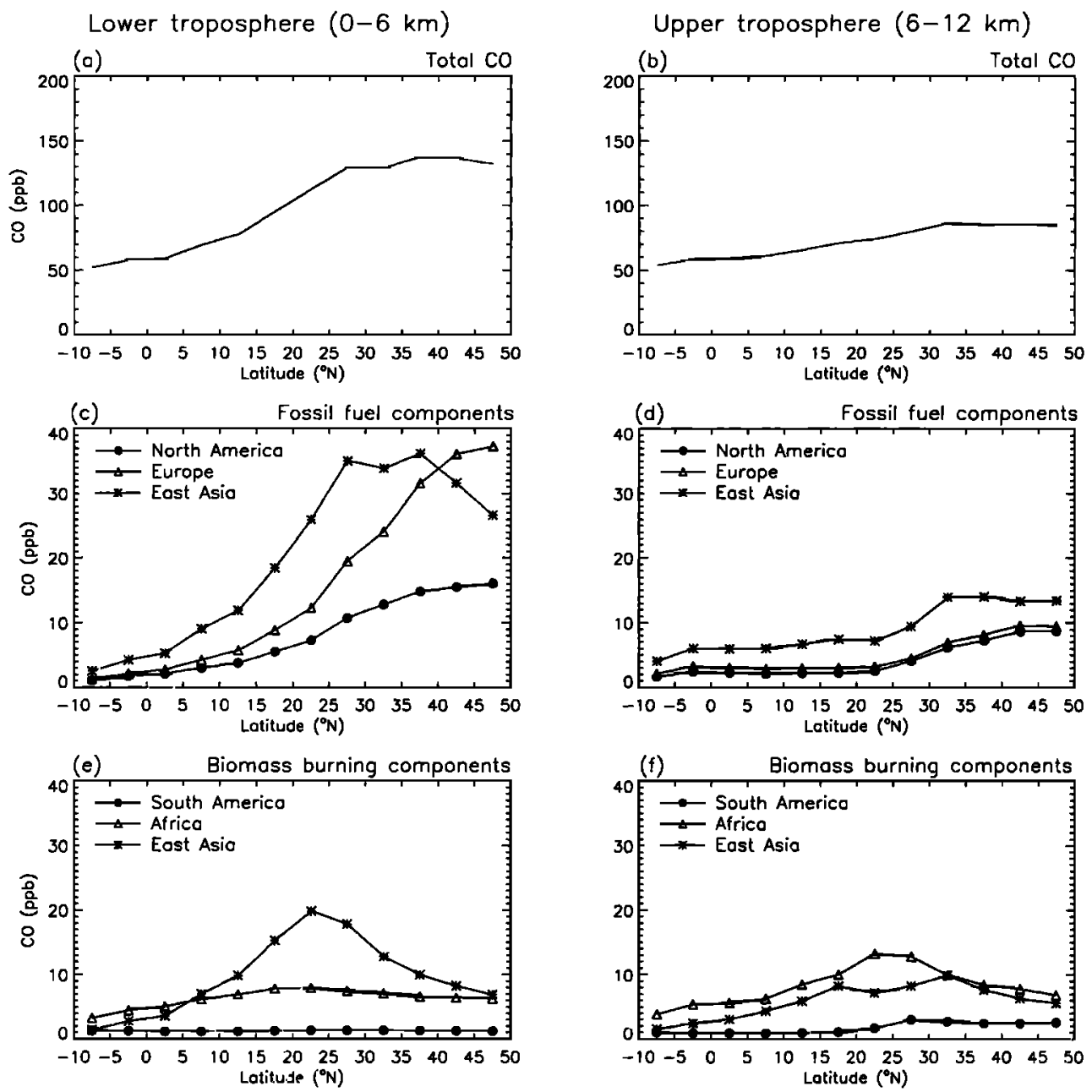

Figure 12. CO concentrations (ppb) as function of latitude for the lower troposphere $(0-6 \mathrm{~km})$ and the upper troposphere $(6-12 \mathrm{~km}$ ) contributed by emissions in different geopolitical source regions (Figure 2). Values are model results sampled along the PEM-West B flight tracks. The total CO concentration is thus similar to those shown in Figures $3 \mathrm{a}$ and $3 \mathrm{~b}$.

\section{Export of $\mathrm{NO}_{y}$ and Ozone From Asia}

We isolate the contribution of Asian emissions to the budgets of total reactive nitrogen oxides $\left(\mathrm{NO}_{y}\right)$ and ozone in the Asian boundary layer for the PEM-West B period by subtracting the background terms (given by a simulation with no Asian emissions) from the terms obtained in our standard simulation. We refer to the resulting budgets as those of "Asian" $\mathrm{NO}_{y}$ and ozone. Although this method is only approximate because tropospheric chemistry is not linear, it allows us to isolate the fate of $\mathrm{NO}_{x}$ and other compounds emitted over Asia. The budget of ozone is actually computed for the extended odd oxygen family $\mathrm{O}_{x}$ $=\mathrm{O}_{3}+\mathrm{NO}_{2}+2 \times \mathrm{NO}_{3}+3 \times \mathrm{N}_{2} \mathrm{O}_{5}+\mathrm{HNO}_{4}+\mathrm{HNO}_{3}+$ peroxyacylnitrates to account for rapid chemical cycling within the species in that family. Considering that $\mathrm{O}_{3}$ accounts for more than $95 \%$ of $\mathrm{O}_{x}$, the budget of $\mathrm{O}_{3}$ and $\mathrm{O}_{x}$ can be considered equivalent.

\subsection{Export of $\mathrm{NO}_{y}$ From Asia}

Table 2 summarizes budgets for individual $\mathrm{NO}_{y}$ species in the Asian boundary layer in February-March 1994. We examined the budgets of $\mathrm{NO}_{y}$ from fossil fuel combustion and biomass burning separately. The emission rate of $\mathrm{NO}_{x}$ within the geographical domain is $1.15 \mathrm{Gmol} \mathrm{d}^{-1}$ from fossil fuel combustion and $0.81 \mathrm{Gmol} \mathrm{d}^{-1}$ from biomass burning. Because of the short lifetime of $\mathrm{NO}_{x}(0.4$ days $)$, only a small fraction of the $\mathrm{NO}_{x}$ emitted is exported outside of the boundary layer, $4 \%$ and $6.5 \%$ from fossil fuel combustion and biomass burning, respectively. Most of the $\mathrm{NO}_{x}$ is converted to $\mathrm{HNO}_{3}$ and PANs within the boundary layer. Other organic nitrates represent only a small fraction ( $\sim 3 \%$ ) of total $\mathrm{NO}_{y}$. About $70 \%$ of the $\mathrm{NO}_{y}$ emitted in Asia is lost within the domain by deposition of $\mathrm{HNO}_{3}$. The net export flux of $\mathrm{NO}_{y}$ from the boundary layer to the free troposphere is $0.37 \mathrm{Gmol} \mathrm{d}^{-1}$ (20\% of the $\mathrm{NO}_{x}$ emitted) and is mainly to the western Pacific, as discussed previously for $\mathrm{CO}$. The major component of exported $\mathrm{NO}_{y}$ is PANs (45\%) with $\mathrm{NO}_{x}$ and $\mathrm{HNO}_{3}$ contributing each about 25$30 \%$. PANs are mainly composed of PAN with only $10 \%$ contributed by higher peroxyacylnitrates. Because $\mathrm{HNO}_{3}$ is quickly removed by wet and dry deposition, it cannot represent a significant source of $\mathrm{NO}_{x}$ even after export to the free troposphere. If we do not consider $\mathrm{HNO}_{3}$ in the 
Table 2. Budget for Asian $\mathrm{NO}_{y}$ in the Boundary Layer Over Asia

\begin{tabular}{lllllll}
\hline \multicolumn{1}{c}{ Species } & Concentration & Lifetime & Emissions & P-L & Deposition & Export \\
\hline $\mathrm{NO}_{x}$ & 0.41 & 0.41 & $1.15(0.81)$ & $-1.02(-0.68)$ & $0.05(0.05)$ & $0.04(0.05)$ \\
$\mathrm{PANs}_{\mathrm{HNO}}$ & 0.40 & 0.40 & - & $0.11(0.10)$ & $0.02(0.02)$ & $0.09(0.07)$ \\
Alkylnitrates & 0.73 & 1.2 & - & $0.85(0.53)$ & $0.75(0.48)$ & $0.06(0.05)$ \\
Total & & & - & $0.04(0.05)$ & $0.002(0.001)$ & $0.01(0.004)$ \\
\end{tabular}

Mean model values for February-March 1994 in the Asian boundary layer defined as the region in Figure 2 and for a vertical column extending to $3 \mathrm{~km}$ altitude. Concentrations are given in $\mathrm{ppb}$, lifetime is given in days, and other quantities are given in Gmol $\mathrm{d}^{-1}$. PANs includes PAN and other peroxyacylnitrates. The budget terms are determined by substracting from the standard simulation the background $\mathrm{NO}_{y}$ fluxes obtained with a simulation for which fossil fuel or biomass burning emissions are zeroed within Asia. P-L denotes the net chemical production (production minus loss) in the Asian boundary layer. Emissions, net chemical production, deposition, and export are contributed by fossil fuel combustion (first number) and biomass burning (second number in parentheses).

$\mathrm{NO}_{y}$ exported, the remaining flux is $0.26 \mathrm{Gmol} \mathrm{d}^{-1}(1.4$ $\mathrm{Tg} \mathrm{N} \mathrm{yr}^{-1}$ ), which represents $13 \%$ of the $\mathrm{NO}_{x}$ emitted, with similar contributions from fossil fuel combustion and biomass burning.

Our results can be compared to the export of PANs $+\mathrm{NO}_{x}$ out of the U.S. boundary layer in spring as calculated by Liang et al. [1998] with an earlier version of the Harvard global 3-D model of tropospheric chemistry. With an emission rate of $\mathrm{NO}_{x}$ within the U.S. of $1.34 \mathrm{Gmol} \mathrm{d}^{-1}$ the United States export of PANs+NO $x\left(0.27 \mathrm{Gmol} \mathrm{d}^{-1}\right)$ represented $20 \%$ of the emissions in that study. We find that faster loss of $\mathrm{NO}_{x}$ by heterogeneous hydrolysis of $\mathrm{N}_{2} \mathrm{O}_{5}$ on aerosols is responsible for the lower exported fraction of $\mathrm{NO}_{x}$ emissions out of the Asian boundary layer. Sulfate aerosol concentrations used in our model [Chin et al., 1996] are much higher over Asia than over the United States, reflecting the difference in $\mathrm{SO}_{2}$ emissions. The mean $\mathrm{PAN} / \mathrm{NO}_{x}$ concentration ratio of 1.7 in the Asian outflow in our model is higher than that calculated by Liang et al. [1998] (1.25) but similar to observations obtained during the North Atlantic Regional Experiment (NARE) campaign which flew in spring 1996 along the east coast of North America (D. D. Parrish, personal communication, 2000).

\subsection{Export of Ozone From Asia}

Table 3 shows the budget of ozone in the boundary layer over Asia due solely to Asian emissions of precursors (hydrocarbons, $\mathrm{CO}, \mathrm{NO}_{x}$ ). Background $\mathrm{O}_{3}$ is subtracted following the procedure previously described. Fossil fuel combustion and biomass burning emissions both lead to a similar ozone production of $\sim 9.5 \mathrm{Gmol} \mathrm{d}^{-1}$. Thirty-four percent of the $\mathrm{O}_{3}$ produced is chemically destroyed within the Asian boundary layer, and $21 \%$ is lost by deposition. We calculated the ozone production efficiency (OPE) in the standard model simulation using the definition given by Liu et al. [1987], i.e., the gross number of $\mathrm{O}_{3}$ molecules produced per $\mathrm{NO}_{x}$ molecule oxidized. We find an average value of $12.5 \mathrm{~mol} / \mathrm{mol}$ for the boundary layer over Asia as compared to 3.0 and 9.0 for the boundary layer over the United States in winter and spring, respectively [Liang et al., 1998]. We attribute the high OPE of Asian emissions in our simulation to the lower latitudes; biomass burning in Southeast Asia may be particularly important in that regard.

A total of $9.6 \mathrm{Gmol} \mathrm{d}^{-1}$ of ozone is exported from the Asian boundary layer to the free troposphere. Using $\mathrm{O}_{3} / \mathrm{CO}$ correlations over Asia and Japan, Mauzerall et al. [2000] estimated a yearly averaged export of ozone from China and Japan of $3.3 \mathrm{Gmol} \mathrm{d}^{-1}$. A comparison with our study is difficult because we do not consider the same period nor the same region. Liang et al. [1998] calculated a direct export of ozone from the U.S. boundary layer of $4 \mathrm{Gmol} \mathrm{d}^{-1}$ during spring. The export from the Asian continent appears to be substantially larger.

\section{Summary and Conclusion}

We used a global 3-D model of tropospheric chemistry driven by assimilated meteorology (GEOS-CHEM model)

Table 3. Budget for Asian Ozone in the Boundary Layer Over Asia

\begin{tabular}{lllll}
\hline & Production & Loss & Deposition & Export \\
\hline Anthropogenic ozone & 9.6 & 3.0 & 2.2 & 4.0 \\
Biomass burning ozone & 9.3 & 3.4 & 2.0 & 3.9 \\
Total & 18.9 & 6.4 & 4.2 & 7.9 \\
\hline
\end{tabular}

Mean model values ( $\mathrm{Gmol} \mathrm{d}^{-1}$ ) for February-March 1994 in the Asian boundary layer defined as the region in Figure 2 and for a vertical column extending to $3 \mathrm{~km}$ altitude. The budgets are for the extended odd oxygen family defined as $\mathrm{O}_{3}+\mathrm{NO}_{2}+2 \times \mathrm{NO}_{3}+$ $3 \times \mathrm{N}_{2} \mathrm{O}_{5}+\mathrm{HNO}_{4}+\mathrm{HNO}_{3}+$ peroxyacylnitrates. Contribution from Asian sources are determined by substracting from the standard simulation the background budget terms obtained with a simulation for which anthropogenic or biomass burning sources are zeroed over Asia. 
to examine the Asian outflow of ozone, $\mathrm{CO}$, and $\mathrm{NO}_{y}$ species over the western Pacific by simulation of observations from the PEM-West B aircraft mission in FebruaryMarch 1994. Considerable biomass burning takes place in the northern tropics during that time of year, and we find that emissions of $\mathrm{CO}$ and $\mathrm{NO}_{x}$ from biomass burning in Asia are of comparable magnitude to the regional anthropogenic source. Comparisons of model results to the PEMWest $\mathrm{B}$ observations for $\mathrm{O}_{3}, \mathrm{CO}$, hydrocarbons, $\mathrm{NO}_{x}$, and PAN show that the model reproduces well the latitudinal and vertical distribution of the Asian outflow, with highest concentrations below $6 \mathrm{~km}$ altitude and north of $25^{\circ} \mathrm{N}$.

We find in the model that fast boundary layer outflow from Asia to the western Pacific is largely restricted to high latitudes (north of $35^{\circ} \mathrm{N}$ ) where the westerly flow extends to the surface. The GEOS monthly mean meteorological fields show the presence of a low-level convergence region over central and eastern China which appears to reflect the episodic lifting of warm air ahead of cold fronts advected eastward from central Asia. The frontal lifting plays a critical role for outflow of Asian pollution in the model, as the polluted air brought from the surface to the lower free troposphere over China is then caught in the strong westerly flow. Analysis of model results shows that the strongest Asian outflow over the western Pacific is associated with the passage of these cold fronts. Although the PEM-West $B$ observations (and the model results) show the highest outflow concentrations over the western Pacific to be in the boundary layer $(0-2 \mathrm{~km})$, the maximum outflow fluxes are in fact in the lower free troposphere $(2-5 \mathrm{~km})$. Large-scale convergence over central China is of particular importance for driving the outflow of biomass burning pollution emitted in Southeast Asia. Convective activity over Asia during February-March is largely confined to the tropics, and makes some contribution to the export of biomass burning pollution, but is not as important as large-scale convergence.

The contribution of intercontinental transport of pollution to the Asian outflow over the western Pacific was examined in the model by tagging $\mathrm{CO}$ emitted from different source regions. We find that both anthropogenic sources in Europe and biomass burning in Africa make major contributions to the Asian outflow, with distinct geographical signatures. European pollution dominates the Asian outflow in the lower troposphere at high latitudes, while African pollution is important in the upper troposphere at all latitudes.

A budget analysis for the fate of $\mathrm{NO}_{x}$ emissions in East Asia during February-March 1994 indicates that 5\% is exported out of the Asian boundary layer as $\mathrm{NO}_{x}$ and $8 \%$ as PAN. In comparison, it has been estimated previously that $20 \%$ of $\mathrm{NO}_{x}$ emitted in the United States in spring is exported as $\mathrm{NO}_{x}$ or PAN. The lower export efficiency for Asian emissions reflects higher aerosol concentrations that promote heterogeneous conversion of $\mathrm{NO}_{x}$ to $\mathrm{HNO}_{3}$ by hydrolysis of $\mathrm{N}_{2} \mathrm{O}_{5}$. We find that production of $\mathrm{O}_{3}$ over East Asia and its export to the global atmosphere are much higher than for the United States because of the lower latitude of the Asian sources.
The observations from the PEM-West $B$ mission have been of considerable value as an initial test of our simulation of Asian outflow to the Pacific. This mission was exploratory, however, and it does not provide the data necessary for identifying the source regions contributing to the outflow or for establishing the outflow mechanisms. Further work is needed to test several of the hypotheses presented in the present paper regarding the springtime Asian outflow, notably that (1) lifting of pollution ahead of cold fronts is a major mechanism for export of pollution from China and Southeast Asia to the western Pacific; (2) biomass burning and fossil fuel combustion make contributions of comparable magnitude to the export of Asian $\mathrm{CO}, \mathrm{NO}_{y}$ species, and $\mathrm{O}_{3}$; and (3) intercontinental transport of anthropogenic pollution from Europe and biomass burning pollution in Africa make major contributions to the Asian outflow with distinct geographical signatures. The Transport and Chemical Evolution Over the Pacific (TRACE-P) aircraft mission, to be conducted by NASA in the spring of 2001, should allow significant progress in testing these hypotheses by sampling plumes of Asian outflow over a wide range of conditions.

Acknowledgments. This research was supported by the NASA Atmospheric Chemistry Modeling and Analysis Program. We are grateful to Bryan Duncan for helpful discussions.

\section{References}

Akimoto, H., and $\mathrm{H}$. Narita, Distribution of $\mathrm{SO}_{2}, \mathrm{NO}_{x}$ and $\mathrm{CO}_{2}$ emissions from fuel combustion and industrial activities in Asia with $1^{\circ} \times 1^{\circ}$ resolution, Atmos. Environ., 28, 213-225, 1994.

Allen, D.J., R.B. Rood, A.M. Thompson, and R.D. Hidson, Threedimensional radon-222 calculations using assimilated data and a convective mixing algorithm, J. Geophys. Res., 101, 6871-6881, 1996a.

Allen, D.J., et al., Transport induced interannual variability of carbon monoxide using a chemistry and transport model, $J$. Geophys. Res., 101, 28,655-28,670, 1996b.

Balkanski, Y.J., D.J. Jacob, R. Arimoto, and M.A. Kritz, Longrange transport of radon-222 over the North Pacific Ocean: Implications for continental influence, J. Atmos. Chem., 14, 353374, 1992.

Benkovitz, C.M., M.T Schultz, J. Pacyna, L. Tarrason, J. Dignon, E.C. Voldner, P.A. Spiro, J.A. Logan, and T.E. Graedel, Global gridded inventories for anthropogenic emissions of sulfur and nitrogen, J. Geophys. Res., 101, 29,239-29,253, 1996.

Berntsen, T., I.S.A. Isaksen, W.C. Wang, and X.Z. Liang, Impacts of increased anthropogenic emissions in Asia on tropospheric ozone and climate - A global 3-D model study, Tellus, 48, 13-32, 1996.

Berntsen, T.K., S. Karlsdottir, and D.A. Jaffe, Influence of asian emissions on the composition of air reaching the North Western United States, Geophys. Res. Lett., 26, 2171-2174, 1999.

Bey, I., D.J. Jacob, R.M. Yantosca, J.A. Logan, B. Field, A.M. Fiore, Q. Li, H. Liu, L.J. Mickley, and M. Schultz, Global modeling of tropospheric chemistry with assimilated meteorology: Model description and evaluation, J. Geophys. Res., this issue.

Blake, N.J., et al., Distribution and seasonality of selected hydrocarbons and halocarbons over the western Pacific basin during wintertime, J. Geophys. Res., 102, 28,315-28,333, 1997.

Brown, S.S., R.K. Talukdar, and A.R. Ravishankara, Rate constant for the reaction $\mathrm{OH}+\mathrm{NO}_{2}+\mathrm{M} \rightarrow \mathrm{HNO}_{3}+\mathrm{M}$ under atmospheric conditions, Chem. Phys. Lett., 299, 277-284, 1999a. 
Brown, S.S., R.K. Talukdar, and A.R. Ravishankara, Reconsideration of the rate constants for the reaction of hydroxyl radicals with nitric acid vapor, J. Phys. Chem., 103, 3031-3037, $1999 \mathrm{~b}$.

Carmichael, G.R., I. Uno, M.J. Phadnis, Y. Zhang, and Y. Sunwoo, Tropospheric ozone production and transport in the springtime East Asia, J. Geophys. Res., 103, 10,649-10,671, 1998.

Chan, L.Y., C.Y. Chan, H.Y. Liu, S. Christopher, S.J. Oltmans, and J.M. Harris, A case study on the biomass burning in Southeast Asia and enhancements of tropospheric ozone over Hong Kong, Geophys. Res. Lett., 27, 1479-1482, 2000.

Chen, L.-I., et al., Influence of continental outflow events on the aerosol composition at Cheju Island, South Korea, J. Geophys. Res., 102, 28,551-28,574, 1997.

Chin, M., D.J. Jacob, G.M. Gardner, M.S., Foreman-Fowler, P.A. Spiro, and D.L. Savoie, A global three-dimensional model of tropospheric sulfate, J. Geophys. Res., I01, 18,667-18,690, 1996.

Crawford, J., el al., Implications of large-scale shifts in tropospheric $\mathrm{NO}_{x}$ levels in the remote tropical Pacific, J. Geophys. Res., 102, 28,447-28,468, 1997.

Dentener, F.J., G.R. Carmichael, Y. Zhang, J. Lelieveld, and P.J. Crutzen, Role of mineral aerosol as a reactive surface in the global troposphere, J. Geophys. Res., 101, 22,869-22,889, 1996.

Environmental Protection Agency (EPA), National air quality and emisions trend report, 1995, Rep. EPA-454/R-96-005, Research Triangle Park, N.C., 1996.

Galanter, M., H. Levy II, and G.R. Carmichael, Impacts of biomass burning on tropospheric $\mathrm{CO}, \mathrm{NO}_{x}$, and $\mathrm{O}_{3}, J$. Geophys. Res., $105,6633-6653,2000$.

Hoell, J.M., et al., Pacific Exploratory Mission-West Phase B: February-March 1994, J. Geophys. Res., 102, 28,223-28,240, 1997.

Jacob, D.J., J.A. Logan, and P.P. Murti, Effect of rising Asian emissions on surface ozone in the United States, Geophys. Res. Lett., 26, 2175-2178, 1999.

Jaffe, D., et al., Transport of Asian air pollution to North America, Geophys. Res. Lett., 26, 711-714, 1999.

Kawakami, S., et al., Impact of lightning and convection on reactive nitrogen in the tropical free troposphere, J. Geophys. Res., 102, 28,367-28,384, 1997.

Koike, M., Y. Kondo, S. Kawakami, H. Nakajima, G.L. Gregory, G.W. Sachse, H.B. Singh, E.V. Browell, J.T. Merrill, and R.E. Newell, Reactive nitrogen and its correlation with $\mathrm{O}_{3}$ and $\mathrm{CO}$ over the Pacific in winter and early spring, J. Geophys. Res., 102, 28,385-28,404, 1997.

Liang, J., L. W. Horowitz, D. J. Jacob, Y. Wang, A. M. Fiore, J. A. Logan, G. M. Gardner, and J. W. Munger, Seasonal budgets of reactive nitrogen species and ozone over the United States, and export fluxes to the global atmosphere, J. Geophys. Res., 103, 13,435-13,450, 1998.

Lin, S.J., and R.B. Rood, Multidimensional flux form semiLagrangian transport schemes, Mon. Weather Rev., 124, 20462070, 1996.

Liu, C.M., M. Buhr, and J.T. Merill, Ground-based observations of ozone, carbon monoxide, and sulfur dioxide at Kenting, Taiwan, during the PEM-West B campaign, J. Geophys. Res., $102,28,613-28,625,1997$.

Liu, H., W.L. Chang, S.J. Oltmans, L.Y. Chan, and J.M. Harris, On springtime high events in the lower troposphere from Southeast Asian biomass burning, Atmos. Environ., 33, 2403-2410, 1999.

Liu, S.C., M. Trainer, F.C. Fehsenfeld, D.D. Parrish, E.J. Williams, D.W. Fahey, G. Hubler, and P.C. Murphy, Ozone production in the rural troposphere and implications for regional and global ozone distributions, J. Geophys. Res., 92, 4191-4207, 1987.
Mauzerall, D.L., D. Narita, H. Akimoto, L. Horowitz, S. Walters, D.A. Hauglustaine, and G. Brasseur, Seasonal characteristics of tropospheric ozone production and mixing ratios over East Asia: A global three-dimensional chemical transport model analysis, J. Geophys. Res., 105, 17,895-17,910, 2000.

Merrill, J.T., Atmospheric long range transport to the Pacific Ocean, in Chemical Oceanography, vol. 10, edited by J. P. Riley and R. Duce, pp. 15-50, Academic Press, San Diego, Calif., 1989.

Nguyen, B., N. Mihalopoulos, and J.-P. Putaud, Rice straw burning in Southeast Asia as a source of $\mathrm{CO}$ and $\mathrm{COS}$ to the atmosphere, J. Geophys. Res., 99, 16,435-16,439, 1994.

Nieuwolt, S., Tropical Climatology: An Introduction to the Climates of the Low Latitudes, John Wiley, New York, 1977.

Pickering, K.E., Y.S. Wang, W.K. Tao, C. Price, and J.F. Muller, Vertical distributions of lightning $\mathrm{NO}_{x}$ for use in regional and global chemical transport models, J. Geophys. Res., 103, 31,20331,216, 1998.

Price, C., and D. Rind, A simple lightning parameterization for calculating global lightning distributions, J. Geophys. Res., 97, 9919-9933, 1992.

Schubert, S.D., R.B. Rood, and J. Pfaendtner, An assimilated data set for earth science applications, Bull. Am. Meteorol. Soc., 74, 2331-2342, 1993.

Spivakovsky, C.M., et al., Three-dimensional climatological distribution of tropospheric $\mathrm{OH}$ : Update and evaluation, J. Geophys. Res., 105, 8931-8980, 2000.

Staudt, A.C., D.J. Jacob, J.A. Logan, D. Bachiochi, T.N. Krishnamurti, and G.W. Sachse, Continental sources, transoceanic transport, and interhemispheric exchange of carbon monoxide over the Pacific, J. Geophys. Res., in press, 2001.

Talbot, R.W., et al., Large-scale distributions of tropospheric nitric, formic, and acetic acids over the western Pacific basin during wintertime, J. Geophys. Res., 102, 28,303-28,314, 1997.

van Aardenne, J.A., G.R. Carmichael, H. Levy II, D. Streets, and L. Hordijk, Anthropogenic $\mathrm{NO}_{x}$ emissions in Asia in the period 1990-2020, Atmos. Environ., 33, 63j-646, 1999.

Wang, Y., D.J. Jacob, and J.A. Logan, Global simulation of tropospheric $\mathrm{O}_{3}-\mathrm{NO}_{x}$-hydrocarbon chemistry, 1, Formulation, J. Geophys. Res., 103, 10,713-10,725, 1998.

Watts, I.E.M., Climates of China and Korea, in Climates of Northern and Eastern Asia, edited by H. Arakawa, World Survey of Climatol., vol. 8, chap. 1, Elsevier Sci., New York, 1969.

Yienger, J.J., M. Galanter, T.A. Holloway, M.J. Phadnis, S.K. Guttikunda, G.R. Carmichael, W.J. Moxim, and H. Levy II, Episodic nature of air pollution transport from Asia to North America, J. Geophys. Res., 105, 26,931-26,945, 2000.

Yihui, D., Monsoons Over China, Kluwer Acad., Norwell, Mass., 1994.

Zhang, Y., and G.R. Carmichael, The role of mineral aerosol in tropospheric chemistry in East Asia - A model study, J. Appl. Meteorol., 38, 353-366, 1999.

I. Bey, Swiss Federal Institute of Technology (EPFL), DGRLPAS, CH-1015 Lausanne, Switzerland. (e-mail:

isabelle.bey@epfl.ch)

D. J. Jacob, J. A. Logan, R. M. Yantosca, Division of Engineering and Applied Sciences and Department of Earth and Planetary Sciences, Harvard University, 29 Oxford St., Cambridge, MA 02138. (e-mail: dji; jal; bmy@io.harvard.edu)

(Received August 14, 2000; revised April 16, 2001; accepted April 27, 2001.) 